Clinical Assessment PART of Asthma and
COPD 


\section{Diagnosis of Asthma and COPD}

\section{CHAPTER}

\section{INARODUCHON}

Asthma and chronic obstructive pulmonary disease (COPD) are different chronic inflammatory respiratory disorders that may share a common functional abnormality, that is, poorly reversible airflow limitation [1-4]. According to current guidelines, airflow limitation in asthma is reversible or partly reversible [1], whereas airflow limitation in COPD is poorly reversible or not reversible at all [2].

In the pathogenesis of both asthma and COPD, individual genetic susceptibility and environmental exposures are relevant for disease expression. Cigarette smoking is the major cause of COPD [2]. The causes of asthma are largely unknown, although atopy and allergen exposure have major roles [1, 2]. Asthma is a phenotypically heterogeneous disorder that, over the years, has been divided into many different clinical subtypes. In particular, asthma starting in adulthood, asthma in smokers, noneosinophilic asthma, and asthma in obese subjects are important subtypes in the adult asthma population that are still poorly characterized and that may overlap with COPD [5-7].

The differential diagnosis between asthma and COPD is quite simple when the typical clinical and functional features of either disease are present. It is easy to recognize asthma in a young, atopic, nonsmoking subject with recurrent dyspnea, wheezing, or chest tightness and fully reversible airflow limitation. Similarly, it is easy to diagnose COPD in a subject older than 40, a smoker, who presents with chronic dyspnea, cough, sputum, and fixed airflow limitation and no history of asthma or allergic diseases.

The difficulty comes when trying to make a diagnosis of asthma or COPD in a middle-aged or elderly patient, a smoker, who may be atopic or have a history of asthma, who complains of chronic dyspnea but not wheezing, chronic cough, or sputum, and who presents with poorly reversible airflow limitation. It is also difficult to make a diagnosis of asthma or COPD in a middle-aged or elderly patient who has a clear history of atopy and asthma, bronchodilator reversibility, and recurrent wheezing, but who also smokes and has chronic cough and sputum and dyspnea that are not suppressed by inhaled steroids. In such patients, differential diagnosis might become important from a clinical and therapeutic point of view. Inhaled glucocorticosteroids are the first choice of regular medication in asthma but not in COPD, whereas regular long-acting bronchodilators are the first choice of regular medication in COPD but not in asthma. Thus, in patients with overlapping features, the differential diagnosis between asthma and COPD is important in making the decision to prescribe regular treatment with either steroids or bronchodilators.

\section{DEFNIIONS OF ASTHMAAND COPD}

Asthma is a chronic inflammatory disease of the airways clinically characterized by recurrent respiratory symptoms as follows: dyspnea, wheezing, chest tightness, or cough associated with reversible airflow limitation. Other important features of asthma are an exaggerated responsiveness of the airways to various stimuli, and a specific chronic inflammation of the airways characterized by an increased number of $\mathrm{CD}^{+}$ Th2 lymphocytes, eosinophils, and methacromatic cells in the airway mucosa, and increased thickness of the reticular layer of the epithelial
Fabrizio Luppi ${ }^{1}$ Bianca Beghè ${ }^{\prime}$, Lorenzo Corbetta ${ }^{2}$ and Leonardo M. Fabbri ${ }^{1}$

1Department of Respiratory Diseases, University of Modena and Reggio Emilia, Modena, Italy

2Department of Respiratory Diseases, University of Firenze, Firenze, Italy 
basement membrane. Familial predisposition, atopy, and exposure to allergens and sensitizing agents are important risk factors for asthma, even though the causes of asthma the factors responsible for the development of asthma rather than its exacerbations - remain largely undetermined [1].

COPD is a syndrome characterized by poorly reversible airflow limitation, usually progressive, and often associated with chronic respiratory symptoms, such as dyspnea and/or chronic cough and sputum [2]. COPD is associated with chronic inflammation of the airways that is remarkably different from asthmatic inflammation, and that is characterized by an increased number of $\mathrm{CD}^{+} \mathrm{Th} 1 / \mathrm{Tc} 1$ lymphocytes in the airway mucosa and neutrophils in the lumen, with no increased thickness of the reticular layer of the epithelial basement membrane [8-13]. Even though genetic and familial predisposition as well as occupational exposure are considered risk factors, cigarette smoking is by far the most important risk factor for COPD [2].

\section{MINIMUM REQUIREMENIS FOR TH: DIAGNOSIS OFASTHMA OR COPD}

The diagnosis of asthma or COPD is based on clinical history and lung function tests, particularly peak expiratory flow (PEF) and spirometry, with assessment of spontaneous or postbronchodilator reversibility of airflow limitation. Allergy tests are also usually performed for the diagnosis of asthma, but not of COPD patients, to identify allergens responsible for asthma exacerbations and to consider the opportunity to treat the patient with immunotherapy.

\section{Symptoms and medical history}

\section{Asthma}

Most patients who are diagnosed with asthma seek medical attention because of respiratory symptoms. A typical feature of asthma symptoms is their variability. One or more of the following symptoms - wheezing, chest tightness, cough, and episodic shortness of breath - are reported by more than $90 \%$ of patients with asthma [14]. However, the simple presence of these symptoms is not diagnostic, because identical symptoms may be triggered by different stimuli in nonasthmatics, such as in children by acute viral infections [15]. In some asthmatics, wheezing and chest tightness are absent, and the only symptom the patient complains of may be chronic cough or cough after exercise [16]. This clinical entity is also called "cough-variant asthma;" it is particularly common in children and is often more problematic at night $[17,18]$. Symptoms of asthma may be triggered or worsened by several factors, such as exercise, exposure to allergens, viral infections, and emotions. Recurrent exacerbations of respiratory symptoms, worsening of lung function requiring change of treatment, unscheduled requests for medical assistance, and sometimes hospitalization are also among the characteristic clinical features of asthma.
TABLE 41.1 Differential diagnosis of asthma

\begin{tabular}{|ll} 
Localized pathology & $\begin{array}{l}\text { Inhaled foreign body } \\
\text { Endobronchial tumor } \\
\text { Vocal cord dysfunction }\end{array}$ \\
\hline Diffuse airway pathology & COPD \\
& Eosinophilic bronchitis \\
& Postinfectious airway hyperresponsiveness \\
& Cystic fibrosis \\
& Bronchiectasis \\
& Left ventricular failure \\
& Gastroesophageal reflux \\
& Pulmonary embolism \\
Pulmonary eosinophilia & Drug-induced airway hyperresponsiveness
\end{tabular}

Asthma clusters in families and its genetic determinants appear to be linked to those of other allergic $\mathrm{IgE}$ mediated diseases [19-21]. Thus, a personal or family history of asthma and/or allergic rhinitis, atopic dermatitis, or eczema increases the likelihood of a diagnosis of asthma.

Physical activity is an important cause of symptoms (wheezing and/or cough) for most asthma patients, particularly in children, and for some it is the only cause $[15,16]$. Exercise-induced asthma usually develops not during exercise but $5-10 \mathrm{~min}$ afterward, and it resolves spontaneously within 30-45 min. Prompt relief of symptoms after the use of inhaled beta2-agonist, or their prevention by pretreatment with an inhaled beta2-agonist before exercise, supports a diagnosis of asthma. Important aspects of personal history are exposure to agents known to worsen asthma in the home (heating system, cooking system, house-dust mites), workplace conditions, air-conditioning, pets, cockroaches, environmental tobacco smoke [22-26], or even the general environment (e.g. diesel fumes in traffic [27]).

Since respiratory symptoms of asthma are nonspecific, the differential diagnosis is quite extensive, and the main goal for the physician is to consider and exclude other possible diagnoses (Table 41.1). This is even more important if the response to a trial of therapy (i.e. bronchodilators) has been negative.

Asthma is often classified by severity, but asthma severity changes over time. It also depends not only on the severity of the underlying disease but also on its responsiveness to treatment, which becomes the most important criterion in treated subjects. An asthmatic patient might be completely asymptomatic, either because he or she has mild intermittent asthma and long periods without symptoms even without treatment, or because he or she has severe asthma and is receiving full anti-asthmatic treatment, including systemic steroids.

While respiratory symptoms suggest asthma, the sine qua non for the objective diagnosis of asthma is the presence of reversible airflow limitation in subjects with persistent airways obstruction, and/or airway hyperresponsiveness or increased PEF variability in subjects without airways obstruction [1]. 


\section{COPD}

A clinical diagnosis of COPD should be considered in any patient who has dyspnea, chronic cough, or sputum production, and/or a history of exposure to risk factors for the disease [2]. Most patients who are diagnosed with COPD seek medical attention because of respiratory symptoms, particularly dyspnea [28]. Since the early stages COPD may manifest as chronic cough and sputum production, they may be present even in smokers without airflow limitation. Cough and sputum may precede the development of airflow limitation: in fact, respiratory symptoms may be an important risk factor for the development of COPD $[29,30]$. Regular production of sputum for 3 or more months in 2 consecutive years is defined as chronic bronchitis [31]. In some subjects, chronic cough may be unproductive [32-35], and airflow limitation may develop in the absence of cough. In COPD, dyspnea is characteristically persistent, unlike in asthma where it is variable and progressive [36]. In the early stages of the disease, dyspnea is noted only during the patient's usual effort; as lung function decreases, dyspnea becomes more serious and is present during everyday activities or at rest. Dyspnea is not closely correlated with arterial blood gases; for example, the typical "blue bloater" with peripheral edema, hypoxemia, and hypercapnia has generally less dyspnea than the "pink puffer," who generally does not have these blood gas abnormalities but is much more dyspneic. Wheezing and chest tightness are nonspecific symptoms of COPD and may vary on different days or over the course of a single day. Recurrent exacerbations of respiratory symptoms requiring change of treatment, unscheduled requests for medical assistance, and sometimes hospitalization are also among the characteristic clinical features of COPD.

A detailed medical history of a patient with symptoms suggestive of COPD should include exposure to risk factors (e.g. smoking and occupational or environmental exposures), family history of COPD or other chronic respiratory disease, pattern of symptoms, history of exacerbations, presence of comorbidities, medical treatment, and the patient's quality of life.

Diagnosis and assessment of the severity of COPD are mainly based on the degree of airflow limitation during spirometric measurement. Thus, according to current guidelines, the sine qua non for the diagnosis of COPD is the presence of poorly reversible airflow limitation, that is, the presence of a postbronchodilator forced expiratory volume in $1 \mathrm{~s} /$ forced vital capacity ratio $\left(\mathrm{FEV}_{1} / \mathrm{FVC}\right)<0.70$ and $\mathrm{FEV}_{1}<80 \%$ predicted. These values confirm the presence of airflow limitation that is not fully reversible [2].

Airflow limitation in COPD is due to both small airways disease (obstructive bronchiolitis) and parenchymal destruction (emphysema), the relative contributions of which vary among patients $[1,2]$. In contrast, airflow limitation in asthma is almost exclusively due to airways disease [10]. Imaging (see below), particularly thin-section computed tomography (CT), has been used to quantify emphysema by detecting areas of low attenuation. However, airflow limitation as assessed by $\mathrm{FEV}_{1}$ correlates poorly with the severity of emphysema as evaluated by CT [4], possibly because small airways disease contributes significantly to airflow limitation [37]. Recent progress in CT technology
TABLE 41.2 Differential diagnosis of COPD.

\begin{tabular}{|ll|}
\hline Other airway inflammatory diseases & $\begin{array}{l}\text { Asthma } \\
\text { Bronchiectasis } \\
\text { Diffuse panbronchiolitis }\end{array}$ \\
\hline Infectious airway diseases & Tuberculosis \\
\hline Cardiac diseases & Congestive heart failure \\
\hline
\end{tabular}

has made it possible to detect and quantify airway abnormalities [38, 39], but more work is required before the technique can be used in clinical practice.

Studies in COPD patients recruited by experienced pulmonary specialists in hospitals [40] or by general practitioners in outpatient clinics [41] report that up to $40 \%$ of smokers/ex-smokers with chronic respiratory symptoms and clinical findings compatible with COPD do not fit the spirometric definition of COPD reported above. Thus, even when there is a clear history of COPD - chronic respiratory symptoms, exacerbations, smoking, and age $>50-$ a large proportion of such patients either have normal spirometric values or present with reduced lung volumes (a restrictive pattern), and thus the diagnosis of COPD cannot be confirmed [40, 41]. Clinical features of COPD correlate poorly with airflow limitation. Thus, although not yet recommended by current guidelines, proper diagnosis and assessment of the severity of COPD require more than a comprehensive approach that includes imaging $[38,39]$ assessment of exercise tolerance [42], body mass index [42, 43], and chronic comorbidities (e.g. chronic heart failure (CHF), arterial hypertension, metabolic syndrome) that are often associated with COPD $[44,45]$.

Because chronic respiratory symptoms (particularly dyspnea), clinical features, and poorly reversible airflow limitation may also be present in other pathological conditions, a careful differential diagnosis between COPD and these conditions should always be performed (Table 41.2).

\section{Physical examination}

In mild asthma, physical examination is usually normal under stable conditions but becomes characteristically abnormal during asthma attacks. Typical physical signs of asthma attacks are wheezing on auscultation, cough, expiratory ronchi throughout the chest, and signs of acute hyperinflation (e.g. poor diaphragmatic excursion at percussion, use of accessory muscles of respiration). Some patients, particularly children, may present with a predominant nonproductive cough (cough-variant asthma). In some asthmatics, wheezing - which usually reflects airflow limitation - may be absent or detectable only on forced expiration, even in the presence of significant airflow limitation; this may be due to hyperinflation or to very marked airflow limitation. In these patients, however, the severity of asthma is mostly indicated by other signs, such as cyanosis, drowsiness, difficulty in speaking, tachycardia, hyperinflated chest, use of accessory muscles, and intercostal recession.

In the early stages of COPD, physical examination is usually normal. Current smokers may have signs of active 
smoking, including an odor of smoke or nicotine staining of fingernails. In more severe COPD, prolonged expiration and wheezing and signs of hyperinflation (e.g. barrel chest and poor diaphragmatic excursion at percussion, use of accessory muscles of respiration) are usually present. Cyanosis of the lips and nail beds and signs of cor pulmonale, such as edema of the ankle or lower leg, are often present in patients with reduced oxyhemoglobin percentage. Even though clubbing of the digits may be present in patients with severe COPD and is considered a sign of COPD, it is nonspecific; in fact, its presence should alert the physician to the possible presence of other diseases, particularly lung cancer. Patients with COPD often have reduced breath sounds and wheezing during quiet breathing or after forced expiration.

Physical examination is usually not very useful in making the differential diagnosis between asthma and COPD, but it can be useful in assessing the severity of exacerbations of both asthma and COPD [46].

\section{Lung function tests}

\section{Spirometry}

Lung function tests play a crucial role in the diagnosis and follow-up of asthma and COPD. Spirometric measurements - $\mathrm{FEV}_{1}$ and slow vital capacity (VC) or FVC - are the standard means for assessing airflow limitation. Spirometry is recommended at the time of diagnosis and for the assessment of the severity of both asthma and COPD $[1,2,47,48]$ it should be repeated to monitor the disease and when there is a need for reassessment, such as during exacerbations [3].

Poorly reversible airflow limitation is indicated by the absolute reduction of postbronchodilator $\mathrm{FEV}_{1} / \mathrm{VC}$ or $\mathrm{FEV}_{1} / \mathrm{FVC}$ ratios $<0.7$ but it should be confirmed with postbronchodilator $\mathrm{FEV}_{1} / \mathrm{VC}$ values below the lower limit of normal [4, 49]. Measurements of residual volume and total lung capacity may also be useful in determining the degree of hyperinflation and/or enlargement of airspaces $[1,2,47,48]$.

In asthma, airflow limitation is usually reversible, either spontaneously or after treatment, except for moderate/ severe asthma with fixed airway obstruction $[1,3,10]$. In COPD, airflow limitation is by definition not reversible (i.e. $\mathrm{FEV}_{1} / \mathrm{FVC}$ does not reach 0.7 even after inhalation of a bronchodilator or a short course of long-acting beta2-agonist (LABA) and inhaled steroids). However, up to one-third of COPD patients show a significant increase in $\mathrm{FEV}_{1}(>15 \%)$ after receiving inhaled beta-adrenergic agonists [50-54], which simulate the reversible airflow limitation observed in asthmatics.

In conclusion, while the best spirometric values are useful to define whether airflow obstruction is reversible or not (i.e. does not return within normal values), the degree of reversibility after treatment does not help to make the differential diagnosis between asthma and COPD (see below).

\section{Peak expiratory flow}

An important tool for the diagnosis and subsequent treatment of asthma is the PEF meter [55]. PEF is the highest expiratory flow obtained during a forced expiration starting immediately after a deep inspiration from total lung capacity. $\mathrm{PEF}$ is a simple, reproducible index and can be measured with inexpensive and portable meters [56]. If spirometry does not reveal airflow limitation, the home monitoring of PEF for 2-4 weeks may help to detect an increased variability of airway caliber, and thus help to diagnose asthma [57]. For most asthmatic patients, PEF correlates well with $\mathrm{FEV}_{1}$ [58]. Daily monitoring of PEF (at least in the morning at awakening and in the evening hours, preferably after bronchodilator inhalation) $[1,3]$ is also useful to assess the severity of asthma and its response to treatment, and it can help patients to detect early signs of asthma deterioration [59]. However, PEF measurements have some limitations. PEF is effort dependent and mainly reflects the caliber of large airways and may therefore underestimate the degree of airflow limitation present in peripheral airways [60]. Diurnal variability is calculated as follows:

$$
\frac{\mathrm{PEF}_{\text {max }}-\mathrm{PEF}_{\text {min }} \times 100}{\mathrm{PEF}_{\text {max }}+\mathrm{PEF}_{\text {min }} / 2}
$$

A diurnal variability of PEF of more than $20 \%$ is diagnostic of asthma, and the magnitude of the variability is broadly proportional to disease severity. PEF monitoring may be of use not only in establishing a diagnosis of asthma and assessing its severity, but also in uncovering an occupational cause for asthma. When used in this way, PEF should be measured more frequently than twice daily, and special attention should be paid to changes occurring in and out of the workplace [55, 61-63].

Even though PEF is at least as important to prognosis as $\mathrm{FEV}_{1}$ in moderate to severe COPD [64], PEF monitoring is not frequently used in COPD for various reasons. First, PEF reflects the patency of central airways, and airflow limitation in COPD starts from peripheral airways. Thus, the PEF value may underestimate airflow limitation, particularly if it occurs in peripheral airways. Second, by definition, airflow limitation is poorly reversible in COPD, and thus PEF usually does not vary significantly. Finally, there is only limited evidence to support a role for PEF in detecting COPD exacerbations $[65,66]$.

\section{Reversibility to bronchodilators}

The reversibility of airflow limitation following bronchodilator therapy is no longer an accepted criterion in support of the diagnosis of asthma, or to establish the differential diagnosis between asthma and COPD [1-3]; even though there is a large increase in FEV1, and particularly its return is above the lower limit of normal values, normal expiratory flows after anti-asthma treatment strongly suggests asthma. Subjects with moderate to severe asthma may develop poorly reversible airflow limitation and have a response to treatment but not a return to normal values. Similarly, COPD patients may show a significant response to treatment, even without a return to normal expiratory flows.

In subjects with airflow limitation, an improvement in $\mathrm{FEV}_{1}$ of $>12-15 \%$ predicted and more than $200 \mathrm{ml}$ after administration of a bronchodilator (e.g. $200 \mu \mathrm{g}$ of inhaled salbutamol from a metered dose inhaler) is no longer considered a pathognomonic hallmark of asthma [1], or a 
criterion for differential diagnosis between asthma and COPD [3, 67-69]. In fact, an incomplete response to a single administration of a bronchodilator does not exclude the possibility of reversibility to longer treatment with bronchodilators or steroids $[70,71]$. Thus, more attention should be paid to the response to long-term treatment.

In COPD patients, bronchodilator reversibility testing should generally be performed at least once. Airflow limitation in COPD is usually not reversible, but the onethird of COPD patients who show a significant response to bronchodilator agents $[50,51,53,54,72]$ are likely to benefit from treatment with glucocorticosteroids [73, 74]. The absence of a response to a bronchodilator should never be a reason to withhold bronchodilator therapy, as the response to bronchodilators in COPD is mainly symptomatic rather than functional [75-79]. Bronchodilator responsiveness is a continuous and poorly reproducible variable; thus, classifying patients as responders or nonresponders can be misleading and does not predict disease progression [68].

As recommended by recent guidelines [1], the terms "reversibility" and "variability" should refer to changes in symptoms accompanied by changes in airflow limitation, which occur spontaneously or in response to treatment. At present, however, these terms often refer only to rapid improvements in $\mathrm{FEV}_{1}$ measured within minutes after inhalation of a rapid-acting bronchodilator, for example, after $200-400 \mu \mathrm{g}$ salbutamol or salbutamol and ipratropium bromide $[54,80]$. In contrast, a history of symptoms and/ or functional reversibility (spontaneous or after any kind of treatment) is the essential component in the diagnosis of asthma.

The assessment of reversibility of both clinical features and functional abnormalities may be useful in obtaining the best level of asthma control achievable and/or the best lung function for individual patients [81]. Achieving and maintaining lung function at the best possible level is one of the objectives of both asthma and COPD management $[1,81,82]$.

In summary, while the best spirometric values are useful to define whether airflow obstruction is reversible or not (i.e. does not return within normal values), the degree of reversibility after treatment does not help to make the differential diagnosis between asthma and COPD (see below).

\section{Arterial blood gases}

In severe asthma and COPD and, more importantly, during acute exacerbations of both asthma and COPD, the measurement of arterial blood gases while the patient is breathing air and/or after oxygen administration is essential for the diagnosis of chronic and/or acute respiratory failure. This test should be performed in all patients with clinical signs of acute or chronic respiratory and/or heart failure [2].

\section{Allergy tests}

The presence of allergic disorders in a patient's family history should be investigated in all patients in whom symptoms are suggestive of asthma [83]. A history provides important information about the patient's lifestyle and occupation, both of which influence exposure to allergens and the time and factors possibly involved in onset and in exacerbations of asthma [84, 85]. In asthmatics, the relationship between exposure to one or more allergens and the occurrence of asthma and/or ocular and nasal symptoms should be established [86]. Also, the relationship of symptoms to the time of the year (seasonal pollen asthma) and to the presence of pets in the home should be assessed, together with a description of the patient's living environment with special attention to carpets, pillows, and other dust collectors [87]. Identifying the presence of an allergic component in asthma adds little to the diagnosis, but it can help in identifying potential triggers and directing allergen immunotherapy [1].

Skin tests with all relevant allergens are present in the geographic area in which the patient lives are the primary diagnostic tool in determining allergic status. Deliberate provocation of the airways with a suspected allergen or sensitizing agent may also be helpful in establishing causality, especially in the workplace $[63,88]$. Measurement of specific $\mathrm{IgE}$ is not usually more informative than a skin test, and is more expensive. Measurement of total $\mathrm{IgE}$ in serum has no value as a diagnostic test for atopy. The main limitation of the allergy test is that a positive test does not necessarily mean that the disease is allergic in nature or that it is causing asthma, as some individuals have specific $\mathrm{IgE}$ antibodies without any symptoms. The cost-benefit ratio of performing inhalation tests with allergens or other sensitizing agents should be carefully examined for each patient because of the high cost and the potential risk involved [69].

The assessment of atopy is not useful in COPD. Even though atopy may be a risk factor for both asthma and COPD $[89,90]$, the demonstration of atopy in COPD patients does not help in the identification of potential triggers as in allergic asthma. Allergen immunotherapy has no role in COPD.

\section{ADDIHIONAL TESTS}

While the diagnosis and assessment of severity of asthma and COPD can be fully established on the basis of clinical history and lung function tests (including arterial blood gases, see below), additional tests might be helpful to better characterize individual patients.

\section{Reversibility to corticosteroids}

In patients with airflow limitation that is not reversed by a single dose of a short-acting bronchodilator, a 2-week treatment with oral or inhaled glucocorticosteroids and bronchodilators might be considered. Glucocorticosteroids can be administered orally (e.g. $40 \mathrm{mg}$ daily prednisone) by aerosol (e.g. $2 \mathrm{mg}$ daily beclomethasone, or equivalent) or both [91-93] for at least 14 days [94]. Unfortunately, patients with COPD cannot be separated into discrete groups of glucocorticosteroid responders and nonresponders, and 
thus glucocorticosteroid testing is an unreliable predictor of the benefit from inhaled glucocorticosteroids in individual patients.

Because of their efficacy and infrequent adverse effects, inhaled glucocorticosteroids alone or in combination with long-acting bronchodilators are increasingly used in practice as first-choice therapy to investigate the reversibility of airflow limitation $[74,95,96]$.

In most patients with a clear history of asthma or COPD, the reversibility to glucocorticosteroids confirms the diagnosis, even if significant overlap exists [10]. Asthma is usually responsive to bronchodilators and/or glucocorticosteroids, whereas COPD is usually less responsive or not responsive at all. In asthma, a combination of sputum eosinophilia and increased nitric oxide (NO) levels may be useful in predicting the response to a trial of oral steroids [97, 98], and sputum eosinophilia may also predict the response to steroids in COPD $[99,100]$. However, some COPD patients may show a significant improvement in function after glucocorticosteroid treatment [73], particularly if they present with pathological abnormalities similar to those in asthma.

The simplest and potentially the safest way of identifying these COPD patients is by an ex juvantibus treatment trial with inhaled glucocorticosteroids [92] in combination with long-acting bronchodilators for 6 weeks to 3 months, using the same criteria for reversibility as in the bronchodilator trial $\left(\mathrm{FEV}_{1}\right.$ increase of $200 \mathrm{ml}$ and $\left.12 \%\right)$ [2, 73, 92, 101]. The response to glucocorticosteroids alone or in combination with long-acting bronchodilators should be evaluated with respect to the postbronchodilator $\operatorname{FEV}_{1}[2,4]$.

COPD patients with a response to glucocorticosteroids present some pathological features of asthma, such as a significantly higher number of eosinophils and higher levels of eosinophil cationic protein in their bronchoalveolar lavage fluid, and a thicker reticular basement membrane $[73,101]$.

All long-term studies in COPD have demonstrated the lack of any effect of inhaled glucocorticosteroids on the natural history of COPD, as evaluated by the decline in $\mathrm{FEV}_{1}$ [2, 102-106]. Therefore, given the documented risks of chronic glucocorticosteroid therapy in both asthma [107] and COPD, such as osteoporosis $[102,108]$, the decision to start long-term treatment with inhaled glucocorticosteroids must be made very carefully.

In patients with poorly reversible airflow limitation due to asthma, the beneficial effects of inhaled glucocorticosteroids are likely to overcome the risks of negative systemic effects [74]. However, in patients with poorly reversible airflow limitation due to smoking, this may not be the case, particularly considering that inhaled glucocorticosteroid alone may be associated with increased mortality [109], and that inhaled glucocorticosteroid both alone and in combination with a long-acting beta2-adrenergic agonist may slightly increase the risk of pneumonia in COPD patients $[109,110]$.

\section{Exercise testing}

Exercise testing is useful for assessing the degree of disability, the role of comorbidities, prognosis for survival, presence of exercise-induced hypoxemia, and response to treatment in individuals with COPD. Simple walking tests are increasingly used in the assessment of COPD patients [111]. Severe COPD might be better assessed by a composite score such as BODE (body mass index, degree of airway obstruction, severity of dyspnea, and exercise tolerance), which has been shown to be a better predictor of subsequent survival and is increasingly used in clinical assessment of patients.

\section{Diffusion capacity}

Measurement of the diffusing capacity of the lung for carbon monoxide (Dlco) has been recommended for distinguishing asthma from COPD [112]. In asthma, Dlco is usually normal or increased [10, 113, 114]. In contrast, Dlco is usually reduced in COPD, possibly due to emphysema $[10,114,115]$, but it may also be reduced in smokers without airflow limitation [116]. Dlco is lower in COPD patients than in asthmatics with incomplete reversible airflow limitation [10, 117, 118]. However, patients with severe alpha-1 antitrypsin deficiency may present with normal Dlco, despite having a significant component of fixed airway obstruction and prominent panacinar emphysema on a high-resolution CT (HRCT) scan, suggesting the limitations of measuring Dlco in these patients $[119,120]$.

\section{Airway hyperresponsiveness}

In patients who have symptoms consistent with asthma but have normal lung function, bronchial provocation tests (methacholine, histamine, adenosine 5'-monophosphate, mannitol, and exercise) are helpful in measuring airway hyperresponsiveness and thereby confirming or excluding the diagnosis of active asthma [121, 122]. Methacholine is mainly used to identify bronchial hyperresponsiveness and to guide treatment. Exercise is used as a bronchial provocation test because demonstrating prevention of exerciseinduced asthma is an indication for use of a drug [121].

These measurements are sensitive for a diagnosis of asthma, but they have low specificity [123]. This means that a negative test can be used to exclude a diagnosis of active asthma, but a positive test does not always mean that a patient has asthma [123]. Airway hyperresponsiveness has been described in workers who are acutely exposed to irritants [124, 125], allergic rhinitis [126-128], and other diseases with airflow limitation, such as cystic fibrosis [129-131] and COPD [132-134]. Indeed COPD, especially in current smokers, is often accompanied by airway hyperresponsiveness [135] that is no different from that in asthmatics with a similar degree of airflow limitation $[10,136]$. In patients with fixed airflow limitation, a similar degree of airway hyperresponsiveness was observed in those with a history of COPD and those with a history of asthma [10]. In these patients, hyperresponsiveness might be largely due to the airflow limitation itself.

In conclusion, the measurement of airway hyperresponsiveness may be useful to confirm asthma in subjects with normal baseline lung function, but it is not useful in 
the differential diagnosis between asthma and COPD, particularly when patients have a similar degree of poorly reversible airflow limitation.

\section{Imaging}

While chest radiography may be useful to exclude diseases that may mimic asthma and COPD, it is not required in the confirmation of the diagnosis and management of asthma. The utility of chest radiography is to exclude other conditions that may imitate or complicate asthma, particularly acute asthma. Examples include pneumonia, cardiogenic pulmonary edema, pulmonary thromboembolism, tumors (especially those that result in airway obstruction with resulting peripheral atelectasis), and pneumothorax [137].

A number of novel imaging methods for assessing airway pathology in asthmatic patients have been proposed $[39,138]$. Both direct and indirect signs of airway pathology have been described using HRCT. Direct signs are obtained by measuring airway or bronchial wall thickness, evaluating the ratio of bronchial diameters to adjacent pulmonary arteries, and identifying a lack of bronchial tapering. Indirect signs include foci of mucoid impaction (including the finding of a tree-in-bud configuration of small peripheral lung nodules indicative of bronchiolitis) and mosaic attenuation [139]. Mosaic attenuation is the presence of geographic zones of decreased lung density adjacent to areas of apparent increased lung density in the absence of architectural distortion or honeycombing. This finding may also be seen in patients with diffuse infiltrative lung disease or, more rarely, chronic embolic pulmonary hypertension. In most cases, reliable identification of air trapping resulting in mosaic lung attenuation requires expiratory imaging. During exhalation, areas of air trapping become accentuated, simplifying the differential diagnosis. Each of these methods has serious limitations, and in clinical practice they have not yet proved sufficiently accurate to warrant their use in diagnosing most cases in which extensive airway remodeling has occurred [140].

Airflow limitation in COPD is due to both small airways disease (obstructive bronchiolitis) and parenchymal destruction (emphysema), the relative contributions of which vary among patients $[141,142]$. Thin-section CT has been used to quantify emphysema by detecting low-attenuation areas, and the role of $\mathrm{CT}$ in diagnosing emphysema is well established. However, airflow limitation evaluated by $\mathrm{FEV}_{1}$ does not show a good correlation with the severity of emphysema as evaluated by CT $[143,144]$, because small airways disease appears to contribute significantly to airflow limitation [145]. Recent progress in CT technology has made it possible to detect and quantify airway abnormalities [146]. Theoretically, thin-section CT can depict the dimensions of airways as small as $\sim 1$ to $2 \mathrm{~mm}$ in inner diameter, suggesting that $\mathrm{CT}$ can be used to evaluate airway dimensions in a variety of diseases [141, 142]. Hasegawa and colleagues [38], who developed new software for measuring airway dimension using curved multiplanar reconstruction, demonstrated that airway luminal area and wall area significantly correlated with $\mathrm{FEV}_{1}$ (\% predicted). The correlation coefficients improved as the airways became smaller.
TABLE 41.3 HRCT features in asthma and COPD.

\begin{tabular}{|lllll|}
\hline & $\begin{array}{l}\text { Mild-to- } \\
\text { persistent } \\
\text { asthma }\end{array}$ & $\begin{array}{l}\text { Severe } \\
\text { asthma }\end{array}$ & COPD & $\begin{array}{l}\text { Healthy } \\
\text { subjects }\end{array}$ \\
\hline $\begin{array}{l}\text { Bronchial wall } \\
\text { thickening }\end{array}$ & ++ & +++ & + & - \\
\hline Emphysema & - & + & +++ & - \\
\hline Bronchiectasis & $+/-$ & ++ & - & $+/-$ \\
\hline
\end{tabular}

Scintigraphic approaches may be used to assess COPD or emphysema and to provide functional imaging. Ultrafine ${ }^{133} \mathrm{Xe}$ gas particles are being used for ventilation scintigraphy, including single photon emission CT (SPECT). SPECT imaging has been shown to be more useful than morphologic HRCT in the evaluation of small airways disease, including pulmonary emphysema [147]. Diffusionweighted, hyperpolarized ${ }^{3} \mathrm{He}$ magnetic resonance imaging has been shown to correlate with pulmonary function tests, particularly Dlco [148]. Also, dynamic contrast-enhanced magnetic resonance imaging may detect abnormalities of the pulmonary peripheral microvasculature [149]. These techniques might be useful in the assessment of pulmonary emphysema.

The clinical application of HRCT is mandatory inCOPD patients who are candidates for volume reduction surgery and in whom the regional distribution of emphysema, particularly upper lobe emphysema, is critical for the outcome of the intervention [150-152]. HRCT features of asthma and COPD $[39,153-156]$ are reported in Table 41.3.

\section{Laboratory examinations}

Circulating eosinophils: circulating eosinophilia is a feature of many different lung diseases. In some conditions, eosinophils are increased in the blood but not in the lung tissue; in other diseases, there may be significant eosinophilia in the lung tissue but not in the peripheral blood. In others, there may be lung eosinophilia without any radiographic evidence of disease, as in asthma. Churg-Strauss syndrome (CSS) is characterized by peripheral and pulmonary eosinophilia with infiltrates on chest radiograph. However, the primary features that distinguish CSS from other pulmonary eosinophilic syndromes are the presence of eosinophilic vasculitis in the setting of asthma and the involvement of multiple end organs. Therefore, in these cases it is important to establish a differential diagnosis between these diseases, which may occur without any radiographic evidence of disease. Although perceived to be quite rare, the incidence of this disease seems to have increased in the last few years, particularly in association with various asthma therapies.

Clinical presentation of COPD exacerbation includes worsening of dyspnea, increased cough and sputum, and changes in the aspect of expectorations. 


\section{Biomarkers of respiratory bacterial infections}

Although clinical criteria are still used to determine which patient should be treated with antibiotics [157], these criteria are neither sensitive nor specific enough to exclude other causes of exacerbation of respiratory symptoms in these patients. Novel biomarkers (e.g. pro-calcitonin) have been recommended for guiding antibiotic treatment both in exacerbations of COPD and pneumonia, but these studies need confirmation [158-160].

Other frequent clinical conditions may mimic the symptoms of COPD exacerbation, including congestive heart failure, pneumonia, pneumothorax, pleural effusion and pulmonary embolism [2]. However, COPD is often cited among the risk factors for acute venous thromboembolism and is an independent predictor of pulmonary embolism [161]. In a small series of patients, the prevalence of deep vein thrombosis in patients admitted with acute exacerbation of COPD was 31\% [162, 163]. Similarly, on the basis of ventilation-perfusion lung scintigraphy, the prevalence of pulmonary embolism in patients admitted with acute exacerbation of COPD was as high as 20\% [164]. More recently, Tillie-Leblond et al. [165] explored the prevalence of pulmonary embolism in a cohort of patients with COPD with unexplained dyspnea and found a rate of $25 \%$ in this population. D-dimer is a product of lysis of stabilized fibrin-clot that is considered an indirect marker of coagulation activation. Measurement of plasma D-dimer has a well established diagnostic role in acute pulmonary embolism because of its high negative predictive value [166]. The usefulness of D-dimer testing remains controversial in inpatients, in part due to a high percentage of "positive" D-dimer values among them, which is consequent to a broad spectrum of diseases (other than pulmonary embolism) and procedures related to the hospitalization. Moreover, for inpatients, a negative D-dimer reduces suspicion but its sensitivity is only $89 \%$, unsatisfactory to exclude pulmonary embolism [167]. If the helical contrast CT angiogram is negative and ultrasound is negative, there is still a 5\% false-negative rate for inpatients [168]. There are no convincing data regarding a negative $\mathrm{CT}$ alone for inpatients. Accordingly, CT and D-dimer evidence may add information but conventional pulmonary arteriography may still be required to make a secure diagnosis. In its absence, a "clinical" decision to treat (and suspend treatment, if contraindications supervene) may be required [169].

\section{Troponin and/or N-BNP}

COPD and CHF are common conditions. The diagnosis of $\mathrm{CHF}$ can remain unsuspected in patients with COPD, because shortness of breath is attributed to COPD. Measurement of plasma B-type natriuretic peptide (BNP) levels helps to uncover unsuspected $\mathrm{CHF}$ in patients with COPD and clinical deterioration [170]. Amino-terminal pro-B-type natriuretic peptides (NT-proBNP) are strong and independent prognostic indicators, representing a particularly strong predictor of heart failure or death [171]. This risk is independent of all other variables, including renal function or troponin, and is proportional to the magnitude of NT-proBNP release, with higher risk observed among those with a more marked elevation of the marker. An elevated initial NT-proBNP concentration should prompt consideration of an early invasive management approach. Consideration should be given to repeating the NT-proBNP measurement after $24-72 \mathrm{~h}$ and again at 3-6 months because these follow-up measurements provide more long-term prognostic information than single measures at presentation. In acute ischemic heart disease, an NT-proBNP value $>250 \mathrm{ng} / 1$ is associated with an adverse prognosis. In patients with stable coronary artery disease, measurement may be performed for prognostication purposes at 6- to 18-month intervals. In the case of clinical suspicion of disease progression, a new sample may be warranted.

\section{Alpha-1 antitrypsin}

Severe hereditary deficiency of alpha-1 antitrypsin is usually associated with early-onset panacinar emphysema [172]. Thus, in patients who develop COPD before the age of 45 and/or who have a strong family history of COPD, alpha-1 antitrypsin should be measured; if the serum concentration is $<15-20 \%$ of the normal value, the patient should be considered for alpha-1 antitrypsin augmentation therapy. Like other genetic tests, this test has no clinical value in asthma [21].

\section{Assessment of airway inflammation}

Bronchopulmonary inflammation is markedly different in asthma and COPD [9,12,173-182] (Fig. 41.1).

While airway biopsies and bronchoalveolar lavage clearly distinguish between asthma and COPD in subjects with overlapping features that may provide useful information in research protocols, they are considered too invasive for the diagnosis or staging of either asthma or COPD $[179,183,184]$. In contrast, noninvasive markers of airway inflammation have been increasingly used in research protocols to differentiate asthma from COPD $[183,185]$.

\section{Sputum}

Sputum induction has been widely used in the study of airway inflammation in asthma and COPD because it is a safe, reproducible, and noninvasive technique that can be used repeatedly, even during exacerbations [186-188]. Sputum findings mainly represent the bronchial compartment. Induced sputum from asthmatic patients during stable conditions is usually characterized by a higher percentage of eosinophils and metachromatic cells than that found in samples from healthy subjects $[189,190]$. Sputum neutrophilia may also be present across the range of disease severity; its identification is important, as it is associated with a poor response to glucocorticosteroids [191-193].

In stable conditions, ex- or current smokers with COPD characteristically show an increased total cell number in spontaneous or induced sputum, with a predominance of neutrophils and a small percentage of eosinophils in some subjects $[133,194,195]$. In some smokers with chronic bronchitis, with or without chronic airflow limitation, 


\section{Rights were not granted to include this figure in electronic media. Please refer to the printed publication.}

FIG. 41.1 Photomicrographs showing bronchial biopsy specimens immunostained with anti-EG-2 (eosinophil cationic protein) from a patient with fixed airflow obstruction and a history of COPD (A) and from a patient with fixed airflow obstruction and a history of asthma (B). The two patients had a similar degree of fixed airflow obstruction. In (B), there is prominent eosinophilia beneath the destroyed epithelium that is not present in (A). Photomicrographs showing bronchial biopsy specimens stained with H\&E from a patient with fixed airflow obstruction and a history of COPD (C) and from a patient with fixed airflow obstruction and a history of asthma (D). The two patients had a similar degree of fixed airflow obstruction. In (D), there is a thicker reticular layer of the epithelial basement membrane compared with (C) (from Ref. [10]). an excess proportion of eosinophils $(>3 \%)$ in lower respiratory secretions (called "eosinophilic bronchitis") can also occur [100, 186, 187]. A recent study has elegantly shown that in patients with COPD the main cells in sputum are neutrophils and macrophages, with more macrophages and eosinophils than in a sub-phenotype of patients with chronic bronchitis [196].

Analysis of sputum from patients with exacerbations of asthma or COPD has provided interesting new information. Mild exacerbations of asthma induced by tapering the dose of inhaled steroids are associated with sputum eosinophilia $[197,198]$. In contrast, mild exacerbations that are spontaneous are associated with eosinophilia in about $50 \%$ of subjects, but the other $50 \%$ do not have sputum eosinophilia [199]. In children, eosinophilic airway inflammation is associated with deteriorating asthma over time. This is consistent with the hypothesis that airway inflammation has an adverse effect on the prognosis of childhood asthma and suggests a role for monitoring inflammation in asthma management [200]. Severe asthma exacerbations are associated with more prominent sputum neutrophilia [201]. Bronchial neutrophilia has also been observed in bronchial lavage fluid from asthmatics during status asthmaticus [202].

Interestingly, exacerbations of chronic bronchitis or COPD are associated with quite similar changes in sputum cell count. Mild exacerbations of chronic bronchitis or COPD are associated with eosinophilia in sputum and in biopsy specimens [203, 204], whereas severe exacerbations of COPD are associated with sputum neutrophilia [205].

Thus, at least in sputum, the changes in inflammatory cells during exacerbations may be no different in asthma and COPD. Once again, this evidence underlines the similarities between the two diseases and the difficulty in
TABLE 41.4 History, symptoms, and results of pulmonary function tests in the differential diagnosis between asthma and COPD.

\begin{tabular}{|c|c|c|}
\hline & Asthma & COPD \\
\hline Onset & Mainly in childhood & In mid to late adult life \\
\hline Smoking & Usually non-smokers & $\begin{array}{l}\text { Almost invariably } \\
\text { smokers }\end{array}$ \\
\hline $\begin{array}{l}\text { Chronic cough and } \\
\text { sputum }\end{array}$ & Absent & $\begin{array}{l}\text { Frequent (chronic } \\
\text { bronchitis) }\end{array}$ \\
\hline Dyspnoea on effort & $\begin{array}{l}\text { Variable and reversible } \\
\text { to treatment }\end{array}$ & $\begin{array}{l}\text { Constant, poorly } \\
\text { reversible and } \\
\text { progressive }\end{array}$ \\
\hline Nocturnal symptoms & Relatively common & Uncommon \\
\hline Airflow limitation & $\begin{array}{l}\text { Increased diurnal } \\
\text { variability }\end{array}$ & $\begin{array}{l}\text { Normal diurnal } \\
\text { variability }\end{array}$ \\
\hline $\begin{array}{l}\text { Response to } \\
\text { bronchodilator }\end{array}$ & Good & Poor \\
\hline $\begin{array}{l}\text { Airway } \\
\text { hyperresponsiveness }\end{array}$ & $\begin{array}{l}\text { In most patients, with } \\
\text { or without airflow } \\
\text { limitation }\end{array}$ & $\begin{array}{l}\text { In most patients with } \\
\text { airflow limitation }\end{array}$ \\
\hline
\end{tabular}

making a differential diagnosis in those few cases in which clinical findings are not definitive.

Several biochemical markers have been studied in induced sputum from both asthma and COPD patients [206-210] (Table 41.4). Although some markers are markedly different in asthma and COPD, and studying 


\section{Rights were not granted to include this figure in electronic media. Please refer to the printed publication.}

FIG. 41.2 Exhaled breath analysis: current state of standardization, research, and clinical use (from Ref. [212]).

these markers may provide useful information in research protocols, their use in clinical practice has not been shown to be superior to simple cell counts.

\section{Exhaled NO}

While endogenous NO may be involved in the pathophysiology of asthma and COPD [211, 212] (Fig. 41.2), exhaled $\mathrm{NO}$ is increased in atopic asthma [213-217] but less at lesser extent so in nonatopic asthma [218, 219]. Furthermore, exhaled NO is reduced by glucocorticosteroids [220] but not by bronchodilators [221]. Conflicting results have been obtained in COPD [222-228].

In patients with stable COPD, a partial bronchodilator response to inhaled salbutamol is associated with increased exhaled NO and sputum eosinophilia [101]. Taken together with previous findings [73], this suggests that there is a subset of patients with COPD who share some characteristics of asthmatic inflammation and who may be responsive to steroids [100].

\section{DIFFERENIIAL DIAGNOSIS BEIWEEN ASTHMA AND COPD}

In most patients, the clinical presentation and particularly the history provide the strongest diagnostic criteria to distinguish asthma from COPD (Table 41.5). Results of pulmonary function tests, particularly spirometry, that show
TABLE 41.5 Ancillary tests in the differential diagnosis between stable asthma and COPD.

\begin{tabular}{lll} 
Ancillary test & Asthma & COPD \\
$\begin{array}{l}\text { Reversibility to } \\
\text { bronchodilator and/or } \\
\text { glucocorticosteroids }\end{array}$ & Usually present & Usually absent \\
\hline $\begin{array}{l}\text { Lung volumes } \\
\text { Residual volume, total } \\
\text { lung capacity }\end{array}$ & $\begin{array}{l}\text { Usually normal } \\
\text { or, if increased, } \\
\text { reversible }\end{array}$ & $\begin{array}{l}\text { Usually irreversibly } \\
\text { increased }\end{array}$ \\
\hline Diffusion capacity & Normal & Decreased \\
\hline Airway hyperresponsiveness & Increased & Usually not \\
& measurable due to \\
\hline Allergy tests & airflow limitation \\
\hline Imaging of the chest & Often positive & Often negative \\
\hline Sputum & Usually normal & Usually abnormal \\
\hline Exhaled No & Eosinophilia & Neutrophilia \\
\hline
\end{tabular}

a nearly complete reversibility of airflow limitation may help to confirm a diagnosis of asthma, and those that show poorly reversible airflow limitation may help to confirm the diagnosis of COPD (Table 41.5).

Differential diagnosis between asthma and COPD becomes more difficult in elderly patients, in whom some 
features may overlap, such as smoking and atopy, and, more importantly, when the patient develops poorly reversible airflow limitation that responds only partially to treatment. In these cases, symptoms, lung function, airway responsiveness, imaging, and even pathological findings may overlap and thus may not provide solid information for the differential diagnosis. Because the differential diagnosis mainly aims to provide better treatment, it is important in these cases to undertake an individual approach and to perform additional tests. Reversibility to corticosteroids alone or in combination with long-acting bronchodilators, measurements of lung volumes and diffusion capacity, analysis of sputum and exhaled NO, and imaging of the chest may demonstrate whether asthma or COPD is the predominant cause of airflow limitation (Table 41.5). In contrast, reversibility to bronchodilator and assessment of airway hyperresponsiveness or skin testing may not be useful in these patients.

\section{COMORBIDITIES OF ASTHMA AND COPD}

The coexistence of chronic rhinitis, nasal polyposis, and sinusitis may contribute to the severity of asthma [229, 230]. There is broad evidence to show that adequate treatment of these upper airway diseases is beneficial to asthma by mechanisms that are not clearly understood. The "one airway" concept developed by the WHO ARIA Group [231] has drawn attention to the importance of treating the whole respiratory tract while managing asthma. Gastroesophageal reflux is also occasionally associated with asthma, both in adults and in children [232], but treatment of reflux usually has little overall effect on mild to moderate asthma [233]. Two recent studies [234, 235] indicate that proton-pump inhibitors in patients with symptomatic reflux improve asthma control in severe disease. A frequent and quite important comorbidity of asthma in adults is COPD, most likely due to smoking, which is quite common in asthmatics. Smoking modifies the airway pathology of asthmatics to a COPD-like pattern and reduces the response to treatment [7]. Comorbidities may become important in severe asthmatics, whereas overall they play a less important role overall in the clinical manifestations of mild to moderate asthma [236, 237].

Recent research suggests that inflammation in COPD is not confined to the lungs, because the main risk factor, smoking, may simultaneously cause pulmonary and systemic inflammation. This may account for the observation that patients with COPD often present with one or more comorbid conditions. The most common comorbidities that have been described in association with COPD are hypertension, diabetes, coronary artery disease [238, 239], chronic heart failure [240], pulmonary infections, cancer [241], and pulmonary vascular disease [242, 243].

Comorbidities are highly likely to affect health outcomes in COPD. Progressive respiratory failure accounts for only about one-third of COPD-related deaths: COPD patients are more likely to die of cardiovascular complications or cancer than of respiratory failure [242]. Therefore, factors other than the progression of lung disease must play a substantial role. The number of preexisting comorbidities in patients with COPD is associated with increased inhospital mortality [239]. Comorbid conditions that have been associated in particular with an increased mortality risk in COPD patients include chronic renal failure, cor pulmonale [244], and pulmonary vascular disease [245]. Underlying heart diseases have not been consistently associated with a higher mortality risk. However, since COPD is frequently underreported, it is difficult to make an accurate estimate of how comorbid conditions influence COPD mortality or, conversely, how COPD affects the outcome of other diagnoses [242].

The complexity of chronic comorbidities applies to acute exacerbations of asthma and COPD to a similar extent. Acute exacerbations of respiratory symptoms may be present in several other acute conditions that should always be carefully considered and excluded, such as acute left ventricular failure, pulmonary thromboembolism, pneumonia, metabolic acidosis, and anemia.

\section{ACKNOWHEDGMENIS}

We thank M. McKenney for scientific assistance with the manuscript and E. Veratelli for her scientific secretarial assistance.

Supported by MURST (Grants 60\% and 40\%), Consorzio Ferrara Ricerche (CFR), Associazione per la Cura e la Ricerca dell'Asma (ARCA), Associazione per lo Studio dei Tumori e delle Malattie Polmonari (ASTMP).

\section{References}

1. Global Strategy for Asthma Management and Prevention. Global Initiative for Asthma (GINA), 2007; Available from: http://www. ginasthma.org

2. Global Strategy for the Diagnosis, Management and Prevention of COPD. Global Initiative for Chronic Obstructive Lung Disease (GOLD), 2007; Available from: http://www.goldcopd.org

3. National Heart, Lung, and Blood Institute. National Asthma Education and Prevention Program. Expert Panel Report 3. Guidelines for the Diagnosis and Management of Asthma, 2007, Publication No. 07-4051.

4. Celli BR, MacNee W. Standards for the diagnosis and treatment of patients with COPD: A summary of the ATS/ERS position paper. Eur Respir J 23(6): 932-46, 2004.

5. Bel EH. Clinical phenotypes of asthma. Curr Opin Pulm Med 10(1): 44-50, 2004.

6. Beuther DA, Weiss ST, Sutherland ER. Obesity and asthma. Am J Respir Crit Care Med 174(2): 112-19, 2006.

7. Thomson NC. Smokers with asthma: What are the management options? Am J Respir Crit Care Med 175(8): 749-50, 2007.

8. Baraldo S, Lokar Oliani K, Turato G, Zuin R, Saetta M. The role of lymphocytes in the pathogenesis of asthma and COPD. Curr Med Chem 14(21): 2250-56, 2007.

9. Curtis JL, Freeman CM, Hogg JC. The immunopathogenesis of chronic obstructive pulmonary disease: Insights from recent research. Proc Am Thorac Soc 4(7): 512-21, 2007.

10. Fabbri LM, Romagnoli M, Corbetta L, Casoni G, Busljetic K, Turato G, Ligabue G, Ciaccia A, Saetta M, Papi A. Differences in airway inflammation in patients with fixed airflow obstruction due to asthma or chronic obstructive pulmonary disease. Am J Respir Crit Care Med 167(3): 418-24, 2003. 
11. Hogg JC. Pathophysiology of airflow limitation in chronic obstructive pulmonary disease. Lancet 364(9435): 709-21, 2004.

12. Hogg JC, Chu F, Utokaparch S, Woods R, Elliott WM, Buzatu L, Cherniack RM, Rogers RM, Sciurba FC, Coxson HO, Pare PD. The nature of small-airway obstruction in chronic obstructive pulmonary disease. N Engl J Med 350(26): 2645-53, 2004.

13. MacNee W. Pathogenesis of chronic obstructive pulmonary disease. Proc Am Thorac Soc 2(4): 258-66, discussion 290-91, 2005.

14. Elliott MW, Adams L, Cockcroft A, MacRae KD, Murphy K, Guz A. The language of breathlessness. Use of verbal descriptors by patients with cardiopulmonary disease. Am Rev Respir Dis 144(4): 826-32, 1991.

15. Townshend J, Hails S, McKean M. Diagnosis of asthma in children. BMJ 335(7612): 198-202, 2007.

16. McFadden ER. Exertional dyspnea and cough as preludes to acute attacks of bronchial asthma. N Engl J Med 292(11): 555-59, 1975.

17. Dicpinigaitis PV. Chronic cough due to asthma: ACCP evidence-based clinical practice guidelines. Chest 129(1 Suppl): 75S-79S, 2006.

18. Pavord ID. Cough and asthma. Pulm Pharmacol Ther 17(6): 399-402, 2004.

19. Burrows B, Martinez FD, Cline MG, Lebowitz MD. The relationship between parental and children's serum IgE and asthma. Am J Respir Crit Care Med 152(5 Pt 1): 1497-500, 1995.

20. Burrows B, Martinez FD, Halonen M, Barbee RA, Cline MG. Association of asthma with serum $\mathrm{IgE}$ levels and skin-test reactivity to allergens. N Engl J Med 320(5): 271-77, 1989.

21. Zhang J, Pare PD, Sandford AJ. Recent advances in asthma genetics. Respir Res 9: 4, 2008.

22. Chauhan AJ, Krishna MT, Frew AJ, Holgate ST. Exposure to nitrogen dioxide $\left(\mathrm{NO}_{2}\right)$ and respiratory disease risk. Rev Environ Health 13(1-2): 73-90, 1998.

23. Garrett MH, Hooper BM, Hooper MA. Indoor environmental factors associated with house-dust-mite allergen (Der p 1) levels in southeastern Australian houses. Allergy 53(11): 1060-65, 1998.

24. Garrett MH, Hooper MA, Hooper BM, Abramson MJ. Respiratory symptoms in children and indoor exposure to nitrogen dioxide and gas stoves. Am J Respir Crit Care Med 158(3): 891-95, 1998.

25. Garrett MH, Rayment PR, Hooper MA, Abramson MJ, Hooper BM. Indoor airborne fungal spores, house dampness and associations with environmental factors and respiratory health in children. Clin Exp Allergy 28(4): 459-67, 1998.

26. Jarvis D, Chinn S, Luczynska C, Burney P. Association of respiratory symptoms and lung function in young adults with use of domestic gas appliances. Lancet 347(8999): 426-31, 1996.

27. McCreanor J, Cullinan P, Nieuwenhuijsen MJ, Stewart-Evans J, Malliarou E, Jarup L, Harrington R, Svartengren M, Han IK, OhmanStrickland P, Chung KF, Zhang J. Respiratory effects of exposure to diesel traffic in persons with asthma. N Engl J Med 357(23): 2348-58, 2007.

28. O'Donnell DE, Banzett RB, Carrieri-Kohlman V, Casaburi R, Davenport PW, Gandevia SC, Gelb AF, Mahler DA, Webb KA. Pathophysiology of dyspnea in chronic obstructive pulmonary disease: A roundtable. Proc Am Thorac Soc 4(2): 145-68, 2007.

29. de Marco R, Accordini S, Cerveri I, Corsico A, Anto JM, Kunzli N, Janson C, Sunyer J, Jarvis D, Chinn S, Vermeire P, Svanes C, Ackermann-Liebrich U, Gislason T, Heinrich J, Leynaert B, Neukirch F, Schouten JP, Wjst M, Burney P. Incidence of chronic obstructive pulmonary disease in a cohort of young adults according to the presence of chronic cough and phlegm. Am J Respir Crit Care Med 175(1): 32-39, 2007.

30. Viegi G, Pistelli F, Sherrill DL, Maio S, Baldacci S, Carrozzi L. Definition, epidemiology and natural history of COPD. Eur Respir J 30(5): 993-1013, 2007.

31. Definition and classification of chronic bronchitis for clinical and epidemiological purposes. A report to the Medical Research Council by their Committee on the Aetiology of Chronic Bronchitis. Lancet 1(7389): 775-9, 1965.
32. Burrows B, Knudson RJ, Cline MG, Lebowitz MD. Quantitative relationships between cigarette smoking and ventilatory function. Am Rev Respir Dis 115(2): 195-205, 1977.

33. Choudry NB, Fuller RW. Sensitivity of the cough reflex in patients with chronic cough. Eur Respir J 5(3): 296-300, 1992.

34. Clark KD, Wardrobe-Wong N, Elliott JJ, Gill PT, Tait NP, Snashall PD. Cigarette smoke inhalation and lung damage in smoking volunteers. Eur Respir J 12(2): 395-99, 1998.

35. Smith J, Woodcock A. Cough and its importance in COPD. Int J Chron Obstruct Pulmon Dis 1(3): 305-14, 2006.

36. Buist AS. Similarities and differences between asthma and chronic obstructive pulmonary disease: Treatment and early outcomes. Eur Respir J Suppl 39: 30s-35s, 2003.

37. Rabe KF, Hurd S, Anzueto A, Barnes PJ, Buist SA, Calverley P, Fukuchi Y, Jenkins C, Rodriguez-Roisin R, van Weel C, Zielinski J. Global strategy for the diagnosis, management, and prevention of chronic obstructive pulmonary disease: GOLD executive summary. $\mathrm{Am}$ J Respir Crit Care Med 176(6): 532-55, 2007.

38. Hasegawa M, Nasuhara Y, Onodera Y, Makita H, Nagai K, Fuke S, Ito Y, Betsuyaku T, Nishimura M. Airflow limitation and airway dimensions in chronic obstructive pulmonary disease. Am J Respir Crit Care Med 173(12): 1309-15, 2006.

39. Mitsunobu F, Tanizaki Y. The use of computed tomography to assess asthma severity. Curr Opin Allergy Clin Immunol 5(1): 85-90, 2005.

40. Kohler D, Fischer J, Raschke F, Schonhofer B. Usefulness of GOLD classification of COPD severity. Thorax 58(9): 825, 2003.

41. Rutten FH, Moons KG, Cramer MJ, Grobbee DE, Zuithoff NP, Lammers JW, Hoes AW. Recognising heart failure in elderly patients with stable chronic obstructive pulmonary disease in primary care: Cross sectional diagnostic study. BMJ 331(7529): 1379, 2005.

42. Celli BR, Cote CG, Marin JM, Casanova C, Montes de Oca M, Mendez RA, Pinto Plata V, Cabral HJ. The body-mass index, airflow obstruction, dyspnea, and exercise capacity index in chronic obstructive pulmonary disease. N Engl J Med 350(10): 1005-12, 2004.

43. Ischaki E, Papatheodorou G, Gaki E, Papa I, Koulouris N, Loukides S. Body mass and fat-free mass indices in COPD: Relation with variables expressing disease severity. Chest 132(1): 164-69, 2007.

44. Fabbri LM, Luppi F, Beghe B, Rabe KF. Complex chronic comorbidities of COPD. Eur Respir J 31(1): 204-12, 2008.

45. Fabbri LM, Rabe KF. From COPD to chronic systemic inflammatory syndrome? Lancet 370(9589): 797-99, 2007.

46. Flaherty KR, Kazerooni EA, Martinez FJ. Differential diagnosis of chronic airflow obstruction. J Asthma 37(3): 201-23, 2000.

47. Miller MR, Hankinson J, Brusasco V, Burgos F, Casaburi R, Coates A, Crapo R, Enright P, van der Grinten CP, Gustafsson P, Jensen R, Johnson DC, MacIntyre N, McKay R, Navajas D, Pedersen OF, Pellegrino R, Viegi G, Wanger J. Standardisation of spirometry. Eur Respir J 26(2): 319-38, 2005.

48. Wanger J, Clausen JL, Coates A, Pedersen OF, Brusasco V, Burgos F, Casaburi R, Crapo R, Enright P, van der Grinten CP, Gustafsson P, Hankinson J, Jensen R, Johnson D, Macintyre N, McKay R, Miller MR, Navajas D, Pellegrino R, Viegi G. Standardisation of the measurement of lung volumes. Eur Respir J 26(3): 511-22, 2005.

49. Pellegrino R, Viegi G, Brusasco V, Crapo RO, Burgos F, Casaburi R, Coates A, van der Grinten CP, Gustafsson P, Hankinson J, Jensen R, Johnson DC, MacIntyre N, McKay R, Miller MR, Navajas D, Pedersen OF, Wanger J. Interpretative strategies for lung function tests. Eur Respir J 26(5): 948-68, 2005.

50. Anthonisen NR, Wright EC. Bronchodilator response in chronic obstructive pulmonary disease. Am Rev Respir Dis 133(5): 814-19, 1986.

51. Calverley PM, Rennard SI. What have we learned from large drug treatment trials in COPD? Lancet 370(9589): 774-85, 2007.

52. Celli BR. The importance of spirometry in COPD and asthma: Effect on approach to management. Chest 117(Suppl 2): 15S-19S, 2000.

53. Soriano JB, Mannino DM. Reversing concepts on COPD irreversibility. Eur Respir J 31(4): 695-96, 2008. 
54. Tashkin DP, Celli B, Decramer M, Liu D, Burkhart D, Cassino C, Kesten S. Bronchodilator responsiveness in patients with COPD. Eur Respir J 31(4): 742-50, 2008.

55. Chiry S, Cartier A, Malo JL, Tarlo SM, Lemiere C. Comparison of peak expiratory flow variability between workers with workexacerbated asthma and occupational asthma. Chest 132(2): 483-88, 2007.

56. Reddel HK, Marks GB, Jenkins CR. When can personal best peak flow be determined for asthma action plans? Thorax 59(11): 922-24, 2004.

57. Wensley D, Silverman M. Peak flow monitoring for guided selfmanagement in childhood asthma: A randomized controlled trial. Am J Respir Crit Care Med 170(6): 606-12, 2004.

58. Stahl E. Correlation between objective measures of airway calibre and clinical symptoms in asthma: A systematic review of clinical studies. Respir Med 94(8): 735-41, 2000

59. Harrison TW, Oborne J, Wilding PJ, Tattersfield AE. Randomised placebo controlled trial of beta agonist dose reduction in asthma. Thorax 54(2): 98-102, 1999.

60. Sawyer G, Miles J, Lewis S, Fitzharris P, Pearce N, Beasley R. Classification of asthma severity: Should the international guidelines be changed? Clin Exp Allergy 28(12): 1565-70, 1998.

61. Kennedy WA, Girard F, Chaboillez S, Cartier A, Cote J, Hargreave F, Labrecque M, Malo JL, Tarlo SM, Redlich CA, Lemiere C. Costeffectiveness of various diagnostic approaches for occupational asthma. Can Respir J14(5): 276-80, 2007.

62. Mapp CE, Boschetto P, Maestrelli P, Fabbri LM. Occupational asthma. Am J Respir Crit Care Med 172(3): 280-305, 2005.

63. Venables KM, Chan-Yeung M. Occupational asthma. Lancet 349(9063): 1465-69, 1997.

64. Hansen EF, Vestbo J, Phanareth K, Kok-Jensen A, Dirksen A. Peak flow as predictor of overall mortality in asthma and chronic obstructive pulmonary disease. Am J Respir Crit Care Med 163(3 Pt 1): 690-93, 2001.

65. Mallia P, Message SD, Kebadze T, Parker HL, Kon OM, Johnston SL. An experimental model of rhinovirus induced chronic obstructive pulmonary disease exacerbations: A pilot study. Respir Res 7: 116, 2006

66. Wilkinson TM, Donaldson GC, Johnston SL, Openshaw PJ Wedzicha JA. Respiratory syncytial virus, airway inflammation, and FEV1 decline in patients with chronic obstructive pulmonary disease. Am J Respir Crit Care Med 173(8): 871-76, 2006.

67. Burge PS, Calverley PM, Jones PW, Spencer S, Anderson JA. Prednisolone response in patients with chronic obstructive pulmonary disease: Results from the ISOLDE study. Thorax 58(8): 654-58, 2003.

68. Calverley PM, Burge PS, Spencer S, Anderson JA, Jones PW. Bronchodilator reversibility testing in chronic obstructive pulmonary disease. Thorax 58(8): 659-64, 2003.

69. Sterk PJ, Fabbri LM, Quanjer PH, Cockcroft DW, O’Byrne PM, Anderson SD, Juniper EF, Malo JL. Airway responsiveness. Standardized challenge testing with pharmacological, physical and sensitizing stimuli in adults. Report Working Party Standardization of Lung Function Tests, European Community for Steel and Coal. Official Statement of the European Respiratory Society. Eur Respir J Suppl 16: 53-83, 1993.

70. Hansen EF, Phanareth K, Laursen LC, Kok-Jensen A, Dirksen A. Reversible and irreversible airflow obstruction as predictor of overall mortality in asthma and chronic obstructive pulmonary disease. $\mathrm{Am} \mathrm{J}$ Respir Crit Care Med 159(4 Pt 1): 1267-71, 1999.

71. Ulrik CS, Backer V. Nonreversible airflow obstruction in life-long nonsmokers with moderate to severe asthma. Eur Respir J 14(4): 892-96, 1999.

72. Gross NJ. COPD: A disease of reversible air-flow obstruction. Am Rev Respir Dis 133(5): 725-26, 1986

73. Chanez P, Vignola AM, O'Shaugnessy T, Enander I, Li D, Jeffery PK, Bousquet J. Corticosteroid reversibility in COPD is related to features of asthma. Am J Respir Crit Care Med 155(5): 1529-34, 1997.

74. Kerstjens HA, Brand PL, Hughes MD, Robinson NJ, Postma DS, Sluiter HJ, Bleecker ER, Dekhuijzen PN, de Jong PM, Mengelers HJ et al. A comparison of bronchodilator therapy with or without inhaled corticosteroid therapy for obstructive airways disease. Dutch Chronic Non-Specific Lung Disease Study Group [see comments]. $N$ Engl J Med 327(20): 1413-19, 1992.

75. Chrystyn H, Mulley BA, Peake MD. Dose response relation to oral theophylline in severe chronic obstructive airways disease. $B M J$ 297(6662): 1506-10, 1988.

76. Gross NJ, Petty TL, Friedman M, Skorodin MS, Silvers GW, Donohue JF. Dose response to ipratropium as a nebulized solution in patients with chronic obstructive pulmonary disease. A three-center study. Am Rev Respir Dis 139(5): 1188-91, 1989.

77. Higgins BG, Powell RM, Cooper S, Tattersfield AE. Effect of salbutamol and ipratropium bromide on airway calibre and bronchial reactivity in asthma and chronic bronchitis. Eur Respir J 4(4): 415-20, 1991.

78. Vathenen AS, Britton JR, Ebden P, Cookson JB, Wharrad HJ, Tattersfield AE. High-dose inhaled albuterol in severe chronic airflow limitation. Am Rev Respir Dis 138(4): 850-55, 1988.

79. Tashkin D, Kesten S. Long-term treatment benefits with tiotropium in COPD patients with and without short-term bronchodilator responses. Chest 123(5): 1441-49, 2003.

80. Decramer M, Celli B, Tashkin DP, Pauwels RA, Burkhart D, Cassino C, Kesten S. Clinical trial design considerations in assessing long-term functional impacts of tiotropium in COPD: The UPLIFT trial. COPD 1(2): 303-12, 2004.

81. Bateman ED, Boushey HA, Bousquet J, Busse WW, Clark TJ, Pauwels RA, Pedersen SE. Can guideline-defined asthma control be achieved? The Gaining Optimal Asthma ControL study. Am J Respir Crit Care Med 170(8): 836-44, 2004.

82. Spencer S, Mayer B, Bendall KL, Bateman ED. Validation of a guideline-based composite outcome assessment tool for asthma control. Respir Res 8: 26, 2007.

83. Hemminki K, Li X, Sundquist K, Sundquist J. Familial risks for asthma among twins and other siblings based on hospitalizations in Sweden. Clin Exp Allergy 37(9): 1320-25, 2007.

84. Berger Z, Rom WN, Reibman J, Kim M, Zhang S, Luo L, FriedmanJimenez G. Prevalence of workplace exacerbation of asthma symptoms in an urban working population of asthmatics. J Occup Environ Med 48(8): 833-39, 2006.

85. Kogevinas M, Zock JP, Jarvis D, Kromhout H, Lillienberg L, Plana E, Radon K, Toren K, Alliksoo A, Benke G, Blanc PD, DahlmanHoglund A, D'Errico A, Hery M, Kennedy S, Kunzli N, Leynaert B, Mirabelli MC, Muniozguren N, Norback D, Olivieri M, Payo F, Villani S, van Sprundel M, Urrutia I, Wieslander G, Sunyer J, Anto JM. Exposure to substances in the workplace and new-onset asthma: An international prospective population-based study (ECRHS-II). Lancet 370(9584): 336-41, 2007.

86. Corren J. The connection between allergic rhinitis and bronchial asthma. Curr Opin Pulm Med 13(1): 13-18, 2007.

87. Apter AJ, Szefler SJ. Advances in adult and pediatric asthma. J Allergy Clin Immunol 117(3): 512-18, 2006

88. Busse WW, Wanner A, Adams K, Reynolds HY, Castro M, Chowdhury B, Kraft M, Levine RJ, Peters SP, Sullivan EJ. Investigative bronchoprovocation and bronchoscopy in airway diseases. Am J Respir Crit Care Med 172(7): 807-16, 2005.

89. Pearce N, Pekkanen J, Beasley R. How much asthma is really attributable to atopy. Thorax 54(3): 268-72, 1999.

90. Weiss ST. Atopy as a risk factor for chronic obstructive pulmonary disease: Epidemiological evidence. Am J Respir Crit Care Med 162(3 Pt 2): S134-36, 2000.

91. Weir DC, Burge PS. Assessment of reversibility of airway obstruction in patients with chronic obstructive airways disease. Thorax 45(11): 907-8, 1990.

92. Weir DC, Burge PS. Effects of high dose inhaled beclomethasone dipropionate, 750 micrograms and 1500 micrograms twice daily, and $40 \mathrm{mg}$ per day oral prednisolone on lung function, symptoms, and bronchial hyperresponsiveness in patients with non-asthmatic chronic airflow obstruction. Thorax 48(4): 309-16, 1993. 
93. Weir DC, Gove RI, Robertson AS, Burge PS. Corticosteroid trials in non-asthmatic chronic airflow obstruction: A comparison of oral prednisolone and inhaled beclomethasone dipropionate. Thorax 45(2): 112-17, 1990.

94. Weir DC, Robertson AS, Gove RI, Burge PS. Time course of response to oral and inhaled corticosteroids in non-asthmatic chronic airflow obstruction. Thorax 45(2): 118-21, 1990.

95. Pauwels RA, Lofdahl CG, Postma DS, Tattersfield AE, O'Byrne P, Barnes PJ, Ullman A. Effect of inhaled formoterol and budesonide on exacerbations of asthma. Formoterol and Corticosteroids Establishing Therapy (FACET) International Study Group [see comments] [published erratum appears in $N$ Engl J Med 338(2): 139, January 1998]. NEngl J Med 337(20): 1405-11, 1997.

96. van Grunsven PM, van Schayck CP, Derenne JP, Kerstjens HA, Renkema TE, Postma DS, Similowski T, Akkermans RP, Pasker-de Jong PC, Dekhuijzen PN, van Herwaarden CL, van Weel C. Long term effects of inhaled corticosteroids in chronic obstructive pulmonary disease: A meta-analysis [see comments]. Thorax 54(1): 7-14, 1999.

97. Little SA, Chalmers GW, MacLeod KJ, McSharry C, Thomson NC. Non-invasive markers of airway inflammation as predictors of oral steroid responsiveness in asthma. Thorax 55(3): 232-34, 2000.

98. Smith AD, Taylor DR. Is exhaled nitric oxide measurement a useful clinical test in asthma? Curr Opin Allergy Clin Immunol 5(1): 49-56, 2005.

99. Brightling CE, McKenna S, Hargadon B, Birring S, Green R, Siva R, Berry M, Parker D, Monteiro W, Pavord ID, Bradding P. Sputum eosinophilia and the short term response to inhaled mometasone in chronic obstructive pulmonary disease. Thorax 60(3): 193-98, 2005.

100. Brightling CE, Monteiro W, Ward R, Parker D, Morgan MD, Wardlaw AJ, Pavord ID. Sputum eosinophilia and short-term response to prednisolone in chronic obstructive pulmonary disease: A randomised controlled trial. Lancet 356(9240): 1480-85, 2000.

101. Papi A, Romagnoli M, Baraldo S, Braccioni F, Guzzinati I, Saetta M, Ciaccia A, Fabbri LM. Partial reversibility of airflow limitation and increased exhaled NO and sputum eosinophilia in chronic obstructive pulmonary disease. Am J Respir Crit Care Med 162(5): 1773-77, 2000.

102. The Lung Health Study Research Group. Effect of inhaled triamcinolone on the decline in pulmonary function in chronic obstructive pulmonary disease. N Engl J Med 343(26): 1902-9, 2000.

103. Burge PS, Calverley PM, Jones PW, Spencer S, Anderson JA, Maslen TK. Randomised, double blind, placebo controlled study of fluticasone propionate in patients with moderate to severe chronic obstructive pulmonary disease: The ISOLDE trial. BMJ 320(7245): 1297-303, 2000.

104. Paggiaro PL, Dahle R, Bakran I, Frith L, Hollingworth K, Efthimiou J. Multicentre randomised placebo-controlled trial of inhaled fluticasone propionate in patients with chronic obstructive pulmonary disease. International COPD Study Group. Lancet 351(9105): 773-80, 1998.

105. Pauwels RA, Lofdahl CG, Laitinen LA, Schouten JP, Postma DS, Pride NB, Ohlsson SV. Long-term treatment with inhaled budesonide in persons with mild chronic obstructive pulmonary disease who continue smoking. European Respiratory Society Study on Chronic Obstructive Pulmonary Disease. N Engl J Med 340(25): 1948-53, 1999.

106. Vestbo J, Sorensen T, Lange P, Brix A, Torre P, Viskum K. Long-term effect of inhaled budesonide in mild and moderate chronic obstructive pulmonary disease: A randomised controlled trial. Lancet 353(9167): 1819-23, 1999.

107. Wong CA, Walsh LJ, Smith CJ, Wisniewski AF, Lewis SA, Hubbard R, Cawte S, Green DJ, Pringle M, Tattersfield AE. Inhaled corticosteroid use and bone-mineral density in patients with asthma. Lancet 355(9213): 1399-403, 2000.

108. Mapp CE. Inhaled glucocorticoids in chronic obstructive pulmonary disease. N Engl J Med 343(26): 1960-61, 2000.
109. Calverley PM, Anderson JA, Celli B, Ferguson GT, Jenkins C, Jones PW, Yates JC, Vestbo J. Salmeterol and fluticasone propionate and survival in chronic obstructive pulmonary disease. $N$ Engl J Med 356(8): 775-89, 2007.

110. Nannini LJ, Cates CJ, Lasserson TJ, Poole P. Combined corticosteroid and long-acting beta-agonist in one inhaler versus inhaled steroids for chronic obstructive pulmonary disease. Cochrane Database Syst Rev (4): CD006826, 2007.

111. Brown CD, Wise RA. Field tests of exercise in COPD: The sixminute walk test and the shuttle walk test. COPD 4(3): 217-23, 2007.

112. Macintyre N, Crapo RO, Viegi G, Johnson DC, van der Grinten CP, Brusasco V, Burgos F, Casaburi R, Coates A, Enright P, Gustafsson P, Hankinson J, Jensen R, McKay R, Miller MR, Navajas D, Pedersen OF, Pellegrino R, Wanger J. Standardisation of the singlebreath determination of carbon monoxide uptake in the lung. Eur Respir J 26(4): 720-35, 2005.

113. Collard P, Njinou B, Nejadnik B, Keyeux A, Frans A. Single breath diffusing capacity for carbon monoxide in stable asthma. Chest 105(5): 1426-29, 1994.

114. Sin BA, Akkoca O, Saryal S, Oner F, Misirligil Z. Differences between asthma and COPD in the elderly. I Investig Allergol Clin Immunol 16(1): 44-50, 2006.

115. Clausen JL. The diagnosis of emphysema, chronic bronchitis, and asthma. Clin Chest Med 11(3): 405-16, 1990.

116. Sansores RH, Pare P, Abboud RT. Effect of smoking cessation on pulmonary carbon monoxide diffusing capacity and capillary blood volume. Am Rev Respir Dis 146(4): 959-64, 1992.

117. Boulet LP, Turcotte H, Hudon C, Carrier G, Maltais F. Clinical, physiological and radiological features of asthma with incomplete reversibility of airflow obstruction compared with those of COPD. Can Respir J 5(4): 270-77, 1998.

118. Papi A, Romagnoli M, Bellettato CM, Cogo AL, Zanin A, Turato G, Saetta M, Ciaccia A, Fabbri LM. Pulmonary function and pathology in asthma and chronic obstructive pulmonary disease (COPD) with similar degree of irreversible airflow limitation. Eur Respir J 16(Suppl 31): 551s, 2000.

119. Wilson JS, Galvin JR. Normal diffusing capacity in patients with PiZ alpha(1)-antitrypsin deficiency, severe airflow obstruction, and significant radiographic emphysema. Chest 118(3): 867-71, 2000.

120. Holme J, Stockley RA. Radiologic and clinical features of COPD patients with discordant pulmonary physiology: Lessons from alpha1antitrypsin deficiency. Chest 132(3): 909-15, 2007.

121. Anderson SD. Provocative challenges to help diagnose and monitor asthma: Exercise, methacholine, adenosine, and mannitol. Curr Opin Pulm Med 14(1): 39-45, 2008.

122. Cockcroft DW, Hargreave FE. Airway hyperresponsiveness. Relevance of random population data to clinical usefulness. Am Rev Respir Dis 142(3): 497-500, 1990.

123. Birnbaum S, Barreiro TJ. Methacholine challenge testing: Identifying its diagnostic role, testing, coding, and reimbursement. Chest 131(6): 1932-35, 2007.

124. Miedinger D, Chhajed PN, Tamm M, Stolz D, Surber C, Leuppi JD. Diagnostic tests for asthma in firefighters. Chest 131(6): 1760-67, 2007.

125. Padoan M, Pozzato V, Simoni M, Zedda L, Milan G, Bononi I, Piola C, Maestrelli P, Boschetto P, Mapp CE. Long-term follow-up of toluene diisocyanate-induced asthma. Eur Respir J 21(4): 637-40, 2003.

126. Allergic Rhinitis and Its Impact on Asthma (ARIA). World Health Organization Initiative. Geneva, 2000.

127. Polosa R, Ciamarra I, Mangano G, Prosperini G, Pistorio MP, Vancheri C, Crimi N. Bronchial hyperresponsiveness and airway inflammation markers in nonasthmatics with allergic rhinitis. Eur Respir J 15(1): 30-35, 2000.

128. Ramsdale EH, Morris MM, Roberts RS, Hargreave FE. Asymptomatic bronchial hyperresponsiveness in rhinitis. J Allergy Clin Immunol 75(5): 573-77, 1985. 
129. Ip M, Lauder IJ, Wong WY, Lam WK, So SY. Multivariate analysis of factors affecting pulmonary function in bronchiectasis. Respiration 60(1): 45-50, 1993.

130. Nielsen KG, Pressler T, Klug B, Koch C, Bisgaard H. Serial lung function and responsiveness in cystic fibrosis during early childhood. Am J Respir Crit Care Med 169(11): 1209-16, 2004.

131. van Haren EH, Lammers JW, Festen J, van Herwaarden CL. Bronchial vagal tone and responsiveness to histamine, exercise and bronchodilators in adult patients with cystic fibrosis. Eur Respir J 5(9): 1083-88, 1992.

132. Grootendorst DC, Rabe KF. Mechanisms of bronchial hyperreactivity in asthma and chronic obstructive pulmonary disease. Proc Am Thorac Soc 1(2): 77-87, 2004

133. Rutgers SR, Timens W, Tzanakis N, Kauffman HF, van der Mark TW, Koeter GH, Postma DS. Airway inflammation and hyperresponsiveness to adenosine $5^{\prime}$-monophosphate in chronic obstructive pulmonary disease. Clin Exp Allergy 30(5): 657-62, 2000.

134. Schafroth Torok S, Leuppi JD. Bronchial hyper-responsiveness and exhaled nitric oxide in chronic obstructive pulmonary disease. Swiss Med Wkly 137(27-28): 385-91, 2007.

135. Scichilone N, Battaglia S, La Sala A, Bellia V. Clinical implications of airway hyperresponsiveness in COPD. Int J Chron Obstruct Pulmon Dis 1(1): 49-60, 2006.

136. James AL, Wenzel S. Clinical relevance of airway remodelling in airway diseases. Eur Respir J 30(1): 134-55, 2007.

137. Sung A, Naidich D, Belinskaya I, Raoof S. The role of chest radiography and computed tomography in the diagnosis and management of asthma. Curr Opin Pulm Med 13(1): 31-36, 2007.

138. Nakano Y, Muller NL, King GG, Niimi A, Kalloger SE, Mishima M, Pare PD. Quantitative assessment of airway remodeling using highresolution CT. Chest 122(Suppl 6): 271S-75S, 2002.

139. Sharma V, Shaaban AM, Berges G, Gosselin M. The radiological spectrum of small-airway diseases. Semin Ultrasound CT MR 23(4): 339-51, 2002.

140. Niimi A, Matsumoto H,Takemura M,Ueda T, Nakano Y, Mishima M. Clinical assessment of airway remodeling in asthma: Utility of computed tomography. Clin Rev Allergy Immunol 27(1): 45-58, 2004.

141. Coxson HO, Rogers RM. Quantitative computed tomography of chronic obstructive pulmonary disease. Acad Radiol 12(11): 1457-63, 2005.

142. Coxson HO, Rogers RM. New concepts in the radiological assessment of COPD. Semin Respir Crit Care Med 26(2): 211-20, 2005.

143. Baldi S, Miniati M, Bellina CR, Battolla L, Catapano G, Begliomini E, Giustini D, Giuntini C. Relationship between extent of pulmonary emphysema by high-resolution computed tomography and lung elastic recoil in patients with chronic obstructive pulmonary disease. Am J Respir Crit Care Med 164(4): 585-89, 2001.

144. Omori H, Fujimoto K, Katoh T. Computed-tomography findings of emphysema: Correlation with spirometric values. Curr Opin Pulm Med 14(2): 110-14, 2008.

145. Hogg JC. State of the art. Bronchiolitis in chronic obstructive pulmonary disease. Proc Am Thorac Soc 3(6): 489-93, 2006.

146. de Jong PA, Muller NL, Pare PD, Coxson HO. Computed tomographic imaging of the airways: Relationship to structure and function. Eur Respir J 26(1): 140-52, 2005.

147. Magnant J, Vecellio L, de Monte M, Grimbert D, Valat C, Boissinot E, Guilloteau D, Lemarie E, Diot P. Comparative analysis of different scintigraphic approaches to assess pulmonary ventilation. J Aerosol Med 19(2): 148-59, 2006.

148. Fain SB, Panth SR, Evans MD, Wentland AL, Holmes JH, Korosec FR, O'Brien MJ, Fountaine H, Grist TM. Early emphysematous changes in asymptomatic smokers: Detection with $3 \mathrm{He} \mathrm{MR}$ imaging. Radiology 239(3): 875-83, 2006.

149. Morino S, Toba T, Araki M, Azuma T, Tsutsumi S, Tao H, Nakamura T, Nagayasu T, Tagawa T. Noninvasive assessment of pulmonary emphysema using dynamic contrast-enhanced magnetic resonance imaging. Exp Lung Res 32(1-2): 55-67, 2006.
150. Fishman A, Martinez F, Naunheim K, Piantadosi S, Wise R, Ries A, Weinmann G, Wood DE. A randomized trial comparing lungvolume-reduction surgery with medical therapy for severe emphysema. N Engl J Med 348(21): 2059-73, 2003.

151. Martinez FJ, Chang A. Surgical therapy for chronic obstructive pulmonary disease. Semin Respir Crit Care Med 26(2): 167-91, 2005.

152. Lenfant C. Will lung volume reduction surgery be widely applied? Ann Thorac Surg 82(2): 385-87, 2006.

153. McLean AN, Sproule MW, Cowan MD, Thomson NC. High resolution computed tomography in asthma. Thorax 53(4): 308-14, 1998.

154. Webb WR. Radiology of obstructive pulmonary disease. AJR Am J Roentgenol 169(3): 637-47, 1997.

155. Boschetto P, Quintavalle S, Zeni E, Leprotti S, Potena A, Ballerin L, Papi A, Palladini G, Luisetti M, Annovazzi L, Iadarola P, De Rosa E, Fabbri LM, Mapp CE. Association between markers of emphysema and more severe chronic obstructive pulmonary disease. Thorax 61(12): 1037-42, 2006.

156. Kurashima K, Takayanagi N, Sato N, Kanauchi T, Hoshi T, Tokunaga D, Ubukata M, Yanagisawa T, Sugita Y, Kanazawa M. High resolution CT and bronchial reversibility test for diagnosing COPD. Respirology 10(3): 316-22, 2005.

157. Anthonisen NR, Manfreda J, Warren CP, Hershfield ES, Harding GK, Nelson NA. Antibiotic therapy in exacerbations of chronic obstructive pulmonary disease. Ann Intern Med 106(2): 196-204, 1987.

158. Stolz D, Christ-Crain M, Morgenthaler NG, Leuppi J, Miedinger D, Bingisser R, Muller C, Struck J, Muller B, Tamm M. Copeptin, $\mathrm{C}$-reactive protein, and procalcitonin as prognostic biomarkers in acute exacerbation of COPD. Chest 131(4): 1058-67, 2007.

159. Stolz D, Christ-Crain M, Bingisser R, Leuppi J, Miedinger D, Muller C, Huber P, Muller B, Tamm M. Antibiotic treatment of exacerbations of COPD: A randomized, controlled trial comparing procalcitonin-guidance with standard therapy. Chest 131(1): 9-19, 2007.

160. Stolz D, Christ-Crain M, Gencay MM, Bingisser R, Huber PR, Muller B, Tamm M. Diagnostic value of signs, symptoms and laboratory values in lower respiratory tract infection. Swiss Med Wkly 136(27-28): 434-40, 2006.

161. Poulsen SH, Noer I, Moller JE, Knudsen TE, Frandsen JL. Clinical outcome of patients with suspected pulmonary embolism. A follow-up study of 588 consecutive patients. J Intern Med 250(2): 137-43, 2001.

162. Schonhofer B, Kohler D. Prevalence of deep-vein thrombosis of the leg in patients with acute exacerbation of chronic obstructive pulmonary disease. Respiration 65(3): 173-77, 1998.

163. Winter JH, Buckler PW, Bautista AP, Smith FW, Sharp PF, Bennett B, Douglas AS. Frequency of venous thrombosis in patients with an exacerbation of chronic obstructive lung disease. Thorax 38(8): $605-8,1983$

164. Erelel M, Cuhadaroglu C, Ece T, Arseven O. The frequency of deep venous thrombosis and pulmonary embolus in acute exacerbation of chronic obstructive pulmonary disease. Respir Med 96(7): 515-18, 2002.

165. Tillie-Leblond I, Marquette CH, Perez T, Scherpereel A, Zanetti C, Tonnel AB, Remy-Jardin M. Pulmonary embolism in patients with unexplained exacerbation of chronic obstructive pulmonary disease: Prevalence and risk factors. Ann Intern Med 144(6): 390-96, 2006

166. Palareti G, Cosmi B, Legnani C. Diagnosis of deep vein thrombosis. Semin Thromb Hemost 32(7): 659-72, 2006.

167. Kuruvilla J, Wells PS, Morrow B, MacKinnon K, Keeney M, Kovacs MJ. Prospective assessment of the natural history of positive $\mathrm{D}$-dimer results in persons with acute venous thromboembolism (DVT or PE). Thromb Haemost 89(2): 284-87, 2003.

168. Musset D, Parent F, Meyer G, Maitre S, Girard P, Leroyer C, Revel MP, Carette MF, Laurent M, Charbonnier B, Laurent F, Mal H, Nonent M, Lancar R, Grenier P, Simonneau G. Diagnostic strategy for patients with suspected pulmonary embolism: A prospective multicentre outcome study. Lancet 360(9349): 1914-20, 2002. 
169. Davidson BL, Tomkowski WZ. Management of pulmonary embolism in 2005. Dis Mon 51(2-3): 116-23, 2005.

170. Le Jemtel TH, Padeletti M, Jelic S. Diagnostic and therapeutic challenges in patients with coexistent chronic obstructive pulmonary disease and chronic heart failure. J Am Coll Cardiol 49(2): 171-80, 2007.

171. Omland T, de Lemos JA. Amino-terminal pro-B-type natriuretic peptides in stable and unstable ischemic heart disease. Am J Cardiol 101(3A): 61-66, 2008.

172. Blanco I, de Serres FJ, Fernandez-Bustillo E, Lara B, Miravitlles M. Estimated numbers and prevalence of $\mathrm{PI}^{*} \mathrm{~S}$ and $\mathrm{PI} Z$ alleles of alpha1-antitrypsin deficiency in European countries. Eur Respir J 27(1): 77-84, 2006.

173. Mauad T, Dolhnikoff M. Pathologic similarities and differences between asthma and chronic obstructive pulmonary disease. Curr Opin Pulm Med 14(1): 31-38, 2008.

174. Bochner BS, Busse WW. Allergy and asthma. J Allergy Clin Immunol 115(5): 953-59, 2005.

175. Busse WW, Lemanske RF Jr. Asthma. N Engl J Med 344(5): 350-62, 2001.

176. Fabbri LM, Romagnoli M, Luppi F, Corbetta L. Asthma versus COPD: Cellular and molecular differences. In: Barnes PJ (ed.), COPD Cellular and Molecular Mechanisms. Lung Biology in Health and Disease Series, pp. 55-81. Marcel Dekker, Inc, New York - Basel, 2004.

177. Jeffery PK. Structural and inflammatory changes in COPD: A comparison with asthma. Thorax 53(2): 129-36, 1998.

178. Fabbri L, Beghe B, Caramori G, Papi A, Saetta M. Similarities and discrepancies between exacerbations of asthma and chronic obstructive pulmonary disease. Thorax 53(9): 803-8, 1998.

179. Fabbri LM, Durham S, Holgate ST, O’Byrne PM, Postma DS. Assessment of airway inflammation: An overview. Eur Respir $J$ (Suppl 26): 6S-8S, 1998.

180. Saetta M. Airway pathology of COPD compared with asthma. Eur Respir Rev 7: 29-33, 1997.

181. Saetta M. Airway inflammation in chronic obstructive pulmonary disease. Am J Respir Crit Care Med 160(5 Pt 2): S17-20, 1999.

182. Saetta M, Timens W, Jeffrey PK. Pathology. In: Postma DS, Siafakas NM (eds.), Management of Chronic Obstructive Pulmonary Disease. Sheffield, UK: Eur Respir Mon ERS Journals Ltd; 92-111,1998.

183. Barnes PJ, Chowdhury B, Kharitonov SA, Magnussen H, Page CP, Postma D, Saetta M. Pulmonary biomarkers in chronic obstructive pulmonary disease. Am J Respir Crit Care Med 174(1): 6-14, 2006.

184. Zhang JY, Wenzel SE. Tissue and BAL based biomarkers in asthma. Immunol Allergy Clin North Am 27(4): 623-32, vi, 2007.

185. Menzies D, Nair A, Lipworth BJ. Non-invasive measurement of airway inflammation in asthma. J Asthma 43(6): 407-15, 2006.

186. Brightling CE. Clinical applications of induced sputum. Chest 129(5): 1344-48, 2006.

187. Hargreave FE, Leigh R. Induced sputum, eosinophilic bronchitis, and chronic obstructive pulmonary disease. Am J Respir Crit Care Med 160(5 Pt 2): S53-57, 1999.

188. Pizzichini MM, Pizzichini E, Clelland L, Efthimiadis A, Mahony J, Dolovich J, Hargreave FE. Sputum in severe exacerbations of asthma: Kinetics of inflammatory indices after prednisone treatment. $\mathrm{Am} \mathrm{J}$ Respir Crit Care Med 155(5): 1501-8, 1997.

189. Kips JC, Fahy JV, Hargreave FE, Ind PW, in't Veen JC. Methods for sputum induction and analysis of induced sputum: A method for assessing airway inflammation in asthma. Eur Respir J Suppl 26: 9S12S, 1998.

190. Pin I, Gibson PG, Kolendowicz R, Girgis-Gabardo A, Denburg JA, Hargreave FE, Dolovich J. Use of induced sputum cell counts to investigate airway inflammation in asthma. Thorax 47(1): 25-29, 1992.

191. Green RH, Brightling CE, Woltmann G, Parker D, Wardlaw AJ, Pavord ID. Analysis of induced sputum in adults with asthma: Identification of subgroup with isolated sputum neutrophilia and poor response to inhaled corticosteroids. Thorax 57(10): 875-79, 2002.
192. Kikuchi S, Nagata M, Kikuchi I, Hagiwara K, Kanazawa M. Association between neutrophilic and eosinophilic inflammation in patients with severe persistent asthma. Int Arch Allergy Immunol 137(Suppl 1): 7-11, 2005.

193. Pavord ID, Brightling CE, Woltmann G, Wardlaw AJ. Noneosinophilic corticosteroid unresponsive asthma. Lancet 353(9171): 2213-14, 1999.

194. Grootendorst DC, Gauw SA, Verhoosel RM, Sterk PJ, Hospers JJ, Bredenbroker D, Bethke TD, Hiemstra PS, Rabe KF. Reduction in sputum neutrophil and eosinophil numbers by the PDE4 inhibitor roflumilast in patients with COPD. Thorax 62(12): 1081-87, 2007.

195. Pizzichini E, Pizzichini MM, Gibson P, Parameswaran K, Gleich GJ, Berman L, Dolovich J, Hargreave FE. Sputum eosinophilia predicts benefit from prednisone in smokers with chronic obstructive bronchitis. Am J Respir Crit Care Med 158(5 Pt 1): 1511-17, 1998.

196. Snoeck-Stroband JB, Lapperre TS, Gosman MM, Boezen HM, Timens W, ten Hacken NH, Sont JK, Sterk PJ, Hiemstra PS. Chronic bronchitis sub-phenotype within COPD: Inflammation in sputum and biopsies. Eur Respir J 31(1): 70-77, 2008.

197. in't Veen JC, Smits HH, Hiemstra PS, Zwinderman AE, Sterk PJ, Bel $\mathrm{EH}$. Lung function and sputum characteristics of patients with severe asthma during an induced exacerbation by double-blind steroid withdrawal. Am J Respir Crit Care Med 160(1): 93-99, 1999.

198. Jatakanon A, Lim S, Barnes PJ. Changes in sputum eosinophils predict loss of asthma control. Am J Respir Crit Care Med 161(1): 64-72, 2000.

199. Turner MO, Hussack P, Sears MR, Dolovich J, Hargreave FE. Exacerbations of asthma without sputum eosinophilia. Thorax 50(10): 1057-61, 1995.

200. Lovett CJ, Whitehead BF, Gibson PG. Eosinophilic airway inflammation and the prognosis of childhood asthma. Clin Exp Allergy 37(11): 1594-601, 2007.

201. Fahy JV, Boushey HA, Lazarus SC, Mauger EA, Cherniack RM, Chinchilli VM, Craig TJ, Drazen JM, Ford JG, Fish JE, Israel E, Kraft M, Lemanske RF, Martin RJ, McLean D, Peters SP, Sorkness C, Szefler SJ. Safety and reproducibility of sputum induction in asthmatic subjects in a multicenter study. Am J Respir Crit Care Med 163(6): 1470-75, 2001.

202. Lamblin C, Gosset P, Tillie-Leblond I, Saulnier F, Marquette CH, Wallaert B, Tonnel AB. Bronchial neutrophilia in patients with noninfectious status asthmaticus. Am J Respir Crit Care Med 157(2): 394-402, 1998.

203. Saetta M, Di Stefano A, Maestrelli P, Turato G, Ruggieri MP, Roggeri A, Calcagni P, Mapp CE, Ciaccia A, Fabbri LM. Airway eosinophilia in chronic bronchitis during exacerbations. Am J Respir Crit Care Med 150(6 Pt 1): 1646-52, 1994.

204. Siva R, Green RH, Brightling CE, Shelley M, Hargadon B, McKenna S, Monteiro W, Berry M, Parker D, Wardlaw AJ, Pavord ID. Eosinophilic airway inflammation and exacerbations of COPD: A randomised controlled trial. Eur Respir J 29(5): 906-13, 2007.

205. Piattella M, Maestrelli P, Saetta M, Mapp C, Caramori G, Ciaccia A, Fabbri LM. Sputum eosinophilia during mild exacerbations and sputum neutrophilia during severe exacerbations of COPD. Am J Respir Crit Care Med 153(Suppl): A822, 1996.

206. Hill AT, Bayley D, Stockley RA. The interrelationship of sputum inflammatory markers in patients with chronic bronchitis. Am J Respir Crit Care Med 160(3): 893-98, 1999.

207. Keatings VM, Barnes PJ. Granulocyte activation markers in induced sputum: Comparison between chronic obstructive pulmonary disease, asthma, and normal subjects. Am J Respir Crit Care Med 155(2): 449-53, 1997.

208. Keatings VM, Barnes PJ. Comparison of inflammatory cytokines in chronic obstructive pulmonary disease, asthma and controls. Eur Respir Rev 7: 146-50, 1997.

209. O’Driscoll BR, Cromwell O, Kay AB. Sputum leukotrienes in obstructive airways diseases. Clin Exp Immunol 55(2): 397-404, 1984. 
210. Pizzichini E, Pizzichini MM, Efthimiadis A, Evans S, Morris MM, Squillace D, Gleich GJ, Dolovich J, Hargreave FE. Indices of airway inflammation in induced sputum: Reproducibility and validity of cell and fluid-phase measurements. Am J Respir Crit Care Med 154(2 Pt 1): 308-17, 1996.

211. Barnes PJ. Nitric oxide and airway disease. Ann Med 27(3): 389-93, 1995.

212. Kharitonov SA, Barnes PJ. Exhaled biomarkers. Chest 130(5): 1541-46, 2006.

213. Alving K, Weitzberg E, Lundberg JM. Increased amount of nitric oxide in exhaled air of asthmatics. Eur Respir J 6(9): 1368-70, 1993.

214. Kharitonov SA, Yates D, Robbins RA, Logan-Sinclair R, Shinebourne EA, Barnes PJ. Increased nitric oxide in exhaled air of asthmatic patients. Lancet 343(8890): 133-35, 1994.

215. Massaro AF, Gaston B, Kita D, Fanta C, Stamler JS, Drazen JM. Expired nitric oxide levels during treatment of acute asthma. Am J Respir Crit Care Med 152(2): 800-3, 1995.

216. Persson MG, Zetterstrom O, Agrenius V, Ihre E, Gustafsson LE. Single-breath nitric oxide measurements in asthmatic patients and smokers. Lancet 343(8890): 146-47, 1994.

217. Turner S. Exhaled nitric oxide in the diagnosis and management of asthma. Curr Opin Allergy Clin Immunol 8(1): 70-76, 2008.

218. Gratziou C, Lignos M, Dassiou M, Roussos C. Influence of atopy on exhaled nitric oxide in patients with stable asthma and rhinitis. Eur Respir J 14(4): 897-901, 1999.

219. Henriksen AH, Lingaas-Holmen T, Sue-Chu M, Bjermer L. Combined use of exhaled nitric oxide and airway hyperresponsiveness in characterizing asthma in a large population survey. Eur Respir $J 15(5): 849-55,2000$.

220. van Rensen EL, Straathof KC, Veselic-Charvat MA, Zwinderman AH, Bel EH, Sterk PJ. Effect of inhaled steroids on airway hyperresponsiveness, sputum eosinophils, and exhaled nitric oxide levels in patients with asthma. Thorax 54(5): 403-8, 1999.

221. Yates DH, Kharitonov SA, Barnes PJ. Effect of short- and longacting inhaled beta2-agonists on exhaled nitric oxide in asthmatic patients. Eur Respir J 10(7): 1483-88, 1997.

222. Corradi M, Majori M, Cacciani GC, Consigli GF, de'Munari E, Pesci A. Increased exhaled nitric oxide in patients with stable chronic obstructive pulmonary disease. Thorax 54(7): 572-75, 1999.

223. Kanazawa H, Shoji S, Yoshikawa T, Hirata K, Yoshikawa J. Increased production of endogenous nitric oxide in patients with bronchial asthma and chronic obstructive pulmonary disease. Clin Exp Allergy 28(10): 1244-50, 1998.

224. Maziak W, Loukides S, Culpitt S, Sullivan P, Kharitonov SA, Barnes PJ. Exhaled nitric oxide in chronic obstructive pulmonary disease. Am J Respir Crit Care Med 157(3 Pt 1): 998-1002, 1998.

225. Robbins RA, Floreani AA, Von Essen SG, Sisson JH, Hill GE, Rubinstein I, Townley RG. Measurement of exhaled nitric oxide by three different techniques. Am J Respir Crit Care Med 153(5): 1631-35, 1996.

226. Rutgers SR, Meijer RJ, Kerstjens HA, van der Mark TW, Koeter GH, Postma DS. Nitric oxide measured with single-breath and tidalbreathing methods in asthma and COPD. Eur Respir J 12(4): 816-19, 1998.

227. Rutgers SR, van der Mark TW, Coers W, Moshage H, Timens W, Kauffman HF, Koeter GH, Postma DS. Markers of nitric oxide metabolism in sputum and exhaled air are not increased in chronic obstructive pulmonary disease. Thorax 54(7): 576-80, 1999.

228. Taylor DR, Pijnenburg MW, Smith AD, De Jongste JC. Exhaled nitric oxide measurements: Clinical application and interpretation. Thorax 61(9): 817-27, 2006.
229. Bresciani M, Paradis L, Des Roches A, Vernhet H, Vachier I, Godard P, Bousquet J, Chanez P. Rhinosinusitis in severe asthma. $J$ Allergy Clin Immunol 107(1): 73-80, 2001.

230. ten Brinke A, Zwinderman AH, Sterk PJ, Rabe KF, Bel EH. Factors associated with persistent airflow limitation in severe asthma. Am J Respir Crit Care Med 164(5): 744-48, 2001.

231. Bachert C, van Cauwenberge P, Khaltaev N. Allergic rhinitis and its impact on asthma. In collaboration with the World Health Organization. Executive summary of the workshop report. December 7-10, 1999, Geneva, Switzerland. Allergy 57(9): 841-55, 2002.

232. Gibson PG, Henry RL, Coughlan JL. Gastro-oesophageal reflux treatment for asthma in adults and children. Cochrane Database Syst Rev (2): CD001496, 2003.

233. Coughlan JL, Gibson PG, Henry RL. Medical treatment for reflux oesophagitis does not consistently improve asthma control: A systematic review. Thorax 56(3): 198-204, 2001.

234. Kiljander TO, Harding SM, Field SK, Stein MR, Nelson HS, Ekelund J, Illueca M, Beckman O, Sostek MB. Effects of esomeprazole $40 \mathrm{mg}$ twice daily on asthma: A randomized placebo-controlled trial. Am J Respir Crit Care Med 173(10): 1091-97, 2006.

235. Littner MR, Leung FW, Ballard ED II, Huang B, Samra NK. Effects of 24 weeks of lansoprazole therapy on asthma symptoms, exacerbations, quality of life, and pulmonary function in adult asthmatic patients with acid reflux symptoms. Chest 128(3): 1128-35, 2005.

236. Slavin RG. Medical management of rhinosinusitis comorbiditiesasthma, aspirin sensitivity, gastroesophageal reflux, immune deficiencies. Clin Allergy Immunol 20: 273-86, 2007.

237. Peroni DG, Piacentini GL, Ceravolo R, Boner AL. Difficult asthma: Possible association with rhinosinusitis. Pediatr Allergy Immunol 18(Suppl 18): 25-27, 2007.

238. Holguin F, Folch E, Redd SC, Mannino DM. Comorbidity and mortality in COPD-related hospitalizations in the United States, 1979 to 2001. Chest 128(4): 2005-11, 2005.

239. Sidney S, Sorel M, Quesenberry CP Jr, DeLuise C, Lanes S, Eisner MD. COPD and incident cardiovascular disease hospitalizations and mortality: Kaiser Permanente Medical Care Program. Chest 128(4): 2068-75, 2005.

240. Sin DD, Wu L, Anderson JA, Anthonisen NR, Buist AS, Burge PS, Calverley PM, Connett JE, Lindmark B, Pauwels RA, Postma DS, Soriano JB, Szafranski W, Vestbo J. Inhaled corticosteroids and mortality in chronic obstructive pulmonary disease. Thorax 60(12): 992-97, 2005.

241. Balkwill F, Mantovani A. Inflammation and cancer: Back to Virchow? Lancet 357(9255): 539-45, 2001.

242. Mannino DM, Watt G, Hole D, Gillis C, Hart C, McConnachie A, Davey Smith G, Upton M, Hawthorne V, Sin DD, Man SF, Van Eeden S, Mapel DW, Vestbo J. The natural history of chronic obstructive pulmonary disease. Eur Respir J 27(3): 627-43, 2006.

243. Sevenoaks MJ, Stockley RA. Chronic Obstructive Pulmonary Disease, inflammation and co-morbidity - a common inflammatory phenotype? Respir Res 7: 70, 2006.

244. Naeije R. Pulmonary hypertension and right heart failure in chronic obstructive pulmonary disease. Proc Am Thorac Soc 2(1): 20-22, 2005.

245. Naeije R, Vizza D. Current perspectives modern hemodynamic evaluation of the pulmonary circulation. Application to pulmonary arterial hypertension and embolic pulmonary hypertension. Ital Heart J 6(10): 784-88, 2005. 